\title{
COMPELLING APPEARANCE IN COURT: ADMINISTRATION OF BAIL IN PHILADELPHIA
}

\author{
Editor's Note-This study was financed by the Institute of \\ Legal Research of the University of Pennsylvania Law School and \\ was completed by editors of the Law Review under the direction \\ of Caleb Foote. $\hat{\dagger}$
}

The right to bail before trial in non-capital cases is guaranteed by constitutional and statutory law." "This traditional right to freedom before conviction," the Supreme Court has said, "permits the unhampered preparation of a defense, and serves to prevent the infliction of punishment prior to conviction. Unless this right to bail before trial is preserved, the presumption of innocence, secured only after centuries of struggle, would lose its meaning." 2 But the right to bail is not an unqualified right to freedom, for the accused may be required to post such security as will reasonably ensure his appearance in court for trial. Certainty of appearance could be guaranteed only by incarcerating all prisoners, whereas not inflicting punishment until guilt is determined would require the abolition of all pre-trial imprisonment. Reconciliation of this conflict is attempted by "properly striking a balance between the need for a tie to the jurisdiction and the right to freedom from unnecessary restraint." 3

This study is an examination of how this adjustment is made in the administration of bail in Philadelphia in non-capital cases before conviction. It includes a survey of the methods employed to set bail, determination of the proportion of defendants who do not obtain bail, the comparative treatment of bail and jail defendants and the relative efficacy of different kinds of bail as deterrents against non-appearance at trial.

†Instructor at Law, University of Pennsylvania Law School. The cooperation of the many persons who assisted in this study is acknowledged with gratitude.

1. U.S. Const. AMIEND. VIII ("Excessive bail shall not be required"); FED. R. CRIM. P. 46 (Before conviction "[a] person arrested for an offense not punishable by death shall be admitted to bail"). See opinion of Mr. Justice Butler as Circuit Justice for the Seventh Circuit in United States v. Motlow, 10 F.2d 657, 659 (7th Cir. 1926) : "The Eighth Amendment provides that 'excessive bail shall not be required." This implies, and therefore safeguards, the right to give bail at least before trial. The purpose is to prevent the practical denial of bail by fixing the amount so unreasonably high that it cannot be given. The provision would be futile if magistrates were left free to deny bail." See Comment, 51 Mrcm. L. REv. 389 (1953). While the Eighth Amendment is not a limitation upon the states, Collins v. Johnston, 237 U.S. 502 (1915), state constitutional and statutory guarantees to bail are parallel, e.g., PA. Const. Art. I, $\$ 14$ ("All prisoners shall be bailable by sufficient sureties, unless for capital offenses where the proof is evident or presumption great"), PA. STAT. ANN. tit. 19, $\$ 51$ (Purdon Supp. 1953). This study does not include problems arising where granting bail is discretionary, as on appeal after conviction, FED. R. CRIM. P. 46(a), or pending trial for capital offenses.

2. Stack v. Boyle, 342 U.S. 1, 4 (1951). 1946).

3. United States ex rel. Rubinstein v. Mulcahy, 155 F.2d 1002, 1004 (2d Cir. 


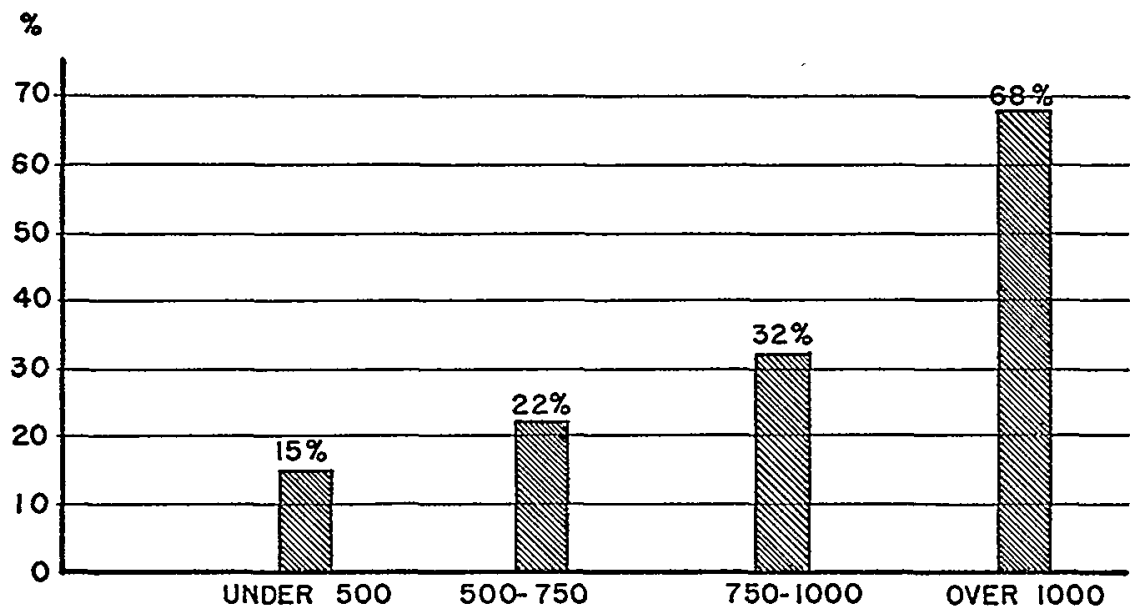

Figure 1. Proportion of State Defendants in Magistrates' Courts Who Did Not Raise Bail According to Amount of Barl.

\section{The Availability of BaIL}

Mr. Justice Jackson has said that: "The practice of admission to bail, as it has evolved in Anglo-American law, is not a device for keeping persons in jail upon mere accusation until it is found convenient to give them a trial. On the contrary, the spirit of the procedure is to enable them to stay out of jail until a trial has found them guilty." 4 If a bail system is to have this effect, it must go as far in facilitating access to bail as is consistent with reasonable assurance that the defendant will present himself at his trial. To make bail readily available, the following standards must be met:

(1) the amount of bail which is required must not be excessive, i.e., it must be no higher than is necessary to compel appearance ${ }^{5}$ and

(2) the procedure must provide for bail to be set promptly after arrest, allow opportunity for the accused to contact potential bondsmen, protect the defendant against exorbitant charges and corrupt practices, and afford an expeditious method of posting the bond.

\section{(a) Determination of Amount of Bail}

The most important of the above requirements is the proscription against excessive bail. The inverse relationship between the amount set and the likelihood that a defendant can post the required security was apparent in both the state and federal cases which were observed (see figures 1 and 2). In the samples which were studied, $73 \%$ of state offenders

4. Stack v. Boyle, 342 U.S. 1, 7-8 (1951) (concurring opinion).

5. U.S. Const. ANEND. VIII; PA. Const. Art. 1, \& 13; Stack v. Boyle, 342 U.S. 1 (1951); United States v. Motlow, 10 F.2d 657 (7th Cir. 1926). 


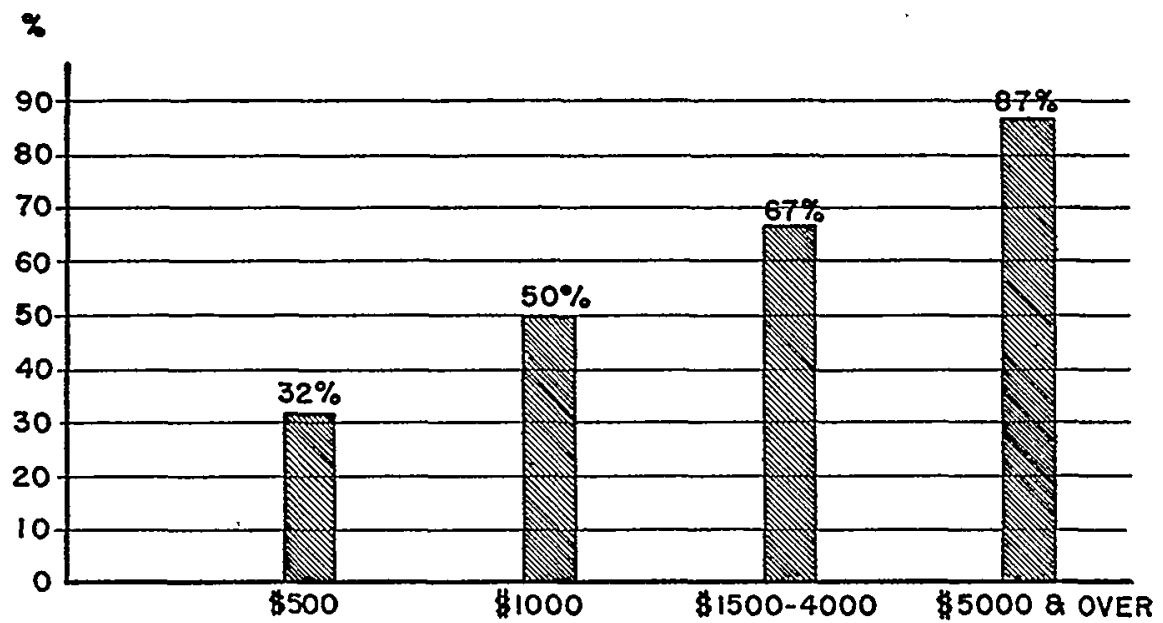

Figure 2. Proportion of Federal Defendants Who Did Not Raise Bail According to Amount of BaIL

for whom magistrates set bail obtained pre-trial release, but in the federal cases, where the range of "normal" bail. is higher by $\$ 500$ or more, this figure was reduced to $53 \%{ }^{6}$ Fifteen per cent of the state sample did not raise bail even when the amount was very low. When the bail was set higher than $\$ 500$, the proportion of offenders who could not put up bond began to rise, and above $\$ 1000$ the proportion was so great that pre-trial release became the exception. At the $\$ 1500$ level the likelihood that the defendant would remain in prison until his trial occurred was four and one-half times as great as at the $\$ 400$ level. In most cases, therefore, the amount of bail will determine whether or not an offender will regain his freedom after arrest. One purpose for imposing a higher amount which would be consistent with the theory of bail would be that the increase in the defendant's financial stake reduces the likelihood of non-appearance at his trial. In practice, however, higher bail usually means that appearance in court is being obtained by holding the defendant behind bars.

In cases involving the constitutional prohibitions against excessive bail, both federal and state courts have clearly articulated that the purpose to be achieved in determining the amount of bail is limited to the objective of insuring appearance for trial. ${ }^{7}$ It follows that release may not be im-

6. See notes $27,29,68$ infra.

7. Stack v. Boyle, 342 U.S. 1 (1951); Ex parte Milburn, 9 Pet. 704, 710 (U.S. 1835); McNair's Petition, 324 Pa. 48, 187 Atl. 498 (1936). 
peded by setting high bail for other purposes, such as punishment or the prevention of possible future criminal activity. ${ }^{8}$ If the amount is higher than that reasonably required to fulfill its legitimate purpose, it is constitutionally excessive. ${ }^{9}$ This limitation recognizes that the defendant is as yet merely an accused. The preliminary hearing at which bail is usually set determines only whether or not there is a prima facie case sufficient to hold the defendant for trial. Since frequently the defendant is not represented and no evidence in his behalf is produced, there is no justification for the imposition of punishment or for a finding of probable future criminality. ${ }^{10}$

The guiding factors for determining the amount of bail are summarized in Federal Rule of Criminal Procedure 46(c) : ${ }^{11}$

"If the defendant is admitted to bail, the amount thereof shall be such as in the judgment of the commissioner or court or judge or justice will insure the presence of the defendant, having regard to the nature and circumstances of the offense charged, the weight of the evidence against him, the financial ability of the defendant to give bail and the character of the defendant."

Courts have also considered the character of the surety, ${ }^{12}$ whether the defendant was a fugitive from justice when apprehended, ${ }^{13}$ a record of previous bail jumping ${ }^{14}$ and, in one case, the difficulty of escape from the jurisdiction (Hawaii). ${ }^{15}$

Except for the nature of the offense charged, these factors vary so greatly in each case that they cannot be reduced to a rule of general applicability; but the administrative problems created by the large volume of

8. See United States v. Foster, 79 F. Supp. 422,423 (S.D.N.Y. 1948).

9. Stack v. Boyle, 342 U.S. 1 (1951) ; Bennett v. United States, 36 F.2d 475 (5th Cir. 1929). See Commonwealth v. Kardosh, 9 Pa. D. \& C. 812 (Northampton County 1927).

10. In Williamson v. United States, 184 F.2d 280, 281-3 (2d Cir. 1950), Mr. Justice Jackson, as Circuit Justice for the Second Circuit, allowed bail to convicted Communists pending an appeal over the contention that the defendants would continue "a course of conduct and activity dangerous to the public welfare, safety and national security of the United States." He said: "Imprisonment to protect society from predicted but unconsummated offenses is so unprecedented in this country and so fraught with danger of excesses and injustice that I am loath to resort to it, even as a discretionary judicial technique to supplement conviction of such offenses as those of which defendants stand convicted." This reasoning applies even more forcefully to the administration of bail before conviction.

11. These standards have come down from the time of Bracton, see 1 Stephen, A History GF the CrIminal LAw of EnGLAND 234 (1883), and were codified in the Habeas Corpus Act of 1679, 31 CAR. II, c. 2. The same standards have been applied in Pennsylvania in the only cases discussing the subject. Commonwealth v. Kardosh, 9 Pa. D. \& C. 812 (Northampton County 1927); Commonwealth v. Williams, $6 \mathrm{~Pa} . \mathrm{D}$. \& C. 162 (Lackawanna County 1924).

12. Ewing v. United States, 240 Fed. 241 (6th Cir. 1917).

13. In re Grimes, 99 Cal. App. 10, 277 Pac. 1052 (1929) (fact that defendant in flight when apprehended warrants high bail).

14. In re Lamar, 294 Fed. 688 (D.N.J. 1924) ; Lee's Case, 15 Fed. Cas. 136, No. 8, 180 (E.D. Pa. 1865).

15. International Longshoreman's Union v. Ackerman, 82 F. Supp. 65 (D. Hawaii 1948), rev'd on other grounds, 187 F.2d 860 (9th Cir.), cert. denied, 342 U.S. 859 (1951). 
cases in which bail must be set necessitates the creation of a standard which can be easily and rapidly applied. It is not surprising, therefore, that the nature of the offense is in fact the basic standard which guides the decision as to the amount to be set. On the appellate level, cases dealing with excessive bail have involved amounts "greater than usually fixed" for similar offenses. ${ }^{16}$ Only then do the courts examine the other variable factors to determine whether the higher amount is warranted by a proportionately higher risk. ${ }^{17}$ The rationale of this reliance on the nature of the offense charged as the standard to guide bail determination is that as the severity of the crime and possible punishment increases, the defendant, having more to fear, becomes more likely to jump bail. Even if this is well founded, ${ }^{18}$ there is no indication of how the range of bail "usually fixed" for a given offense has been established, and within Philadelphia there is a striking difference between the bail usually set in state courts and that usually set in federal courts for comparable offenses. ${ }^{19}$ Judge Clark has noted that this determination on the basis of the nature of the offense "seems to apply an abstract generality as the norm of decision, without consideration of the particular facts and circumstances disclosed" in the individual case. ${ }^{20}$

The "financial ability of the defendant to give bail" ${ }^{21}$ is an obviously relevant guiding standard if the bail system is to effect the release of as many defendants as possible pending trial. If an accused appears to be a good risk, the amount of his bail should be proportioned to his ability to pay; otherwise, high bail is being used to incarcerate dependable persons. While some courts have emphasized the importance of this factor, ${ }^{22}$ inability to raise bail does not in itself render the amount of bail excessive. ${ }^{23}$ The decision as to how much if any consideration should be given to the defendant's financial ability is purely discretionary with the court or magis-

16. See, e.g., Stack v. Boyle, 342 U.S. 1 (1951) (up to $\$ 100,000$ on charges of violating Smith Act); Spector v. United States, 193 F.2d 1002 (9th Cir. 1952) ( $\$ 50,000$ on Smith Act); People ex rel. Sammon v. Snow, 340 I11. 464,173 N.E. 8 (1930) ( $\$ 50,000$ on charge of vagrancy); United States ex rel. Rubinstein v. Mulcahy, 155 F.2d 1002 (2d Cir. 1946) ( $\$ 500,000$ for Selective Service).

17. See note 16 supra. "If bail in an amount greater than that usually fixed for serious charges of crimes is required in the case of any of the petitioners, that is a matter to which evidence should be directed in a hearing so that the constitutional rights of each petitioner may be preserved." Stack v. Boyle, 342 U.S. 1, 6 (1951):

18. See text at notes $25-6$ infra.

19. See text at note 43 infra. 1946).

20. United States ex rel. Rubinstein v. Mulcahy, 155 F.2d 1002, 1005 (2d Cir.

21. Fed. R. Crim. P. 46 (c).

22. Bennett v. United States, 36 F.2d 475, 477 (5th Cir. 1929): "The amount of the bail bond in a criminal case is largely determined by the ability of the defendant to give it, and what would be a reasonable bond in a given case can usually best be determined by the trial judge, because of his familiarity with the facts and the financial ability of the defendant to give security." See Commonwealth v. Kardosh, $9 \mathrm{~Pa}$. D. \& C. 812 (Northampton County 1927).

23. United States v. Rumrich, 180 F.2d 575, 576 (6th Cir. 1950) ("a person arrested upon a criminal charge, who cannot give bail has no recourse but to move for trial") ; Ex parte Malley, 50 Nev. 248, 256 Pac. 512 (1927). 
trate setting bail, provided the amount set is not disproportionate to the general average of bail set for that offense.

In federal cases arising in Philadelphia, a number of defendants who could not post bond were released on their own recognizance when the Commissioner believed that they would appear for trial. Except in cases of assault and battery by automobile, this almost never occurred in the state courts and no information was elicited during bail-setting as to the defendant's financial condition. The elimination of the financial factor resulted in bail being set in amounts which, as Reginald Heber Smith once remarked about legal costs, "are too low to deter the rich, but high enough to prohibit the poor." 24

Other factors which are supposed to be considered, such as the particular circumstances of an offense and the weight of the evidence against the defendant, have the same kind of relevance to the risk of non-appearance as the seriousness of the offense. While this will influence the incentive to flee, its importance is questionable under modern conditions when the more serious the charge, the more likely it is that flight will be followed by a determined and usually successful attempt at apprehension. In Philadelphia it was found that most bail jumping was for minor crimes and that there was none for the most serious offenses. ${ }^{25}$ This emphasizes the fact that the relationship of such standards to the actual risk of non-appearance is unknown. No psychological studies were found which cast any light on the problem of how a court or magistrate can distinguish the reliable from the unreliable defendant, and no tests have been made to determine whether the standards enunciated by judicial or legislative declaration are in fact reliable indicators. An honest attempt to individualize bail determination must be plagued by the treacherous uncertainty inherent in predicting future human behavior. ${ }^{2 \theta}$

Appellate decisions in bail cases are rare. If a defendant is financially unable to raise bail, he probably cannot afford an appeal which might not be decided within the normal period of pre-trial detention. Because the first determination of the amount of bail is in the great majority of cases also the final determination, it is important to observe how the courts' and magistrates' almost unreviewed discretion is actually exercised.

\section{(b) Setting Bail in Philadelphia}

The Philadelphia practices observed in this study involved bail determinations made in three different ways. For most state offenses bail

24. SMith, Justice and the Poor 23 (1919).

25. See text following note 124 infra.

26. Compare the problem of trying to predict recidivism as part of the effort to individualize treatment of criminals. For a review of studies made in this field see Monachesi, American Studies in the Prediction of Recidivism, $41 \mathrm{~J}$. CRIM. L. \& Criminology 268 (1951). There have been no comparable attempts to develop "prediction tables" related to the risk of non-appearance. See, however, a detailed study of 170 untried defendants made by BeEley, The BaIl System in Chicago $59-153$ (1927). See note 155 infra. 
was set during the preliminary hearing before a magistrate. ${ }^{27}$ For certain serious state crimes, of which burglary, robbery, rape, and narcotics offenses are the most important, bail was set by a judge of a common pleas court. $^{28}$ In federal cases, the determination was made by a United States Commissioner. 29

Measured by the number of defendants, the proceedings in the magistrates' courts are by far the most important. The hearings are held each morning at 9 at divisional police courts in dingy station houses throughout the city. Defendants, arrested during the preceding 24 hours, number between two and twenty depending upon the section of the city. They are accompanied by lawyers in only $15 \%$ of the cases. ${ }^{30}$ The magistrate must also dispose of summary offenses, including the overnight drunks. The presiding magistrate is an elected official who is usually not a lawyer ${ }^{31}$ and the assistant district attorney is often the only lawyer present. Police officers and prosecuting witnesses, who are waiting to testify, mingle with spectators in the frequently crowded room. The location, conditions and lack of defense counsel produce an atmosphere which is ill-suited to careful judicial determination.

The primary purpose of the preliminary hearing is to determine whether or not there is a prima facie case sufficient to hold the defendant; and determination of the amount of bail receives, at the most, secondary consideration. After the police evidence has been presented, the defendant is warned, in a sometimes hasty and almost unintelligible manner, of his right not to testify, and then he is given a chance to present a defense. In

27. PA. Srat. ANN. tit. 19, $\$ 51$ (Purdon Supp. 1953) provides that with certain exceptions, see note 28 infra, power to set bail is given to "any judge, justice, mayor, recorder or alderman." In all cases observed in this study where bail was set at the preliminary hearing, the proceedings were before a magistrate, and the material was obtained in two ways. (1) A sample of 48 hearings between June 25 and August 11 , 1953 , in which bail was set in 124 cases, were observed. (2) The transcripts of 861 cases in which bail was set were examined. This sample consisted of cases in the pre-indictment file of the District Attorney's office between June 26 and August 11, 1953.

28. PA. Sat. ANn. tit. 19, $\$ 51$ (Purdon Supp. 1953) provides that bail in these cases can be set by the supreme or common pleas courts or judges thereof or a mayor or recorder of a city. All cases studied involved bail set before a common pleas judge, the sample consisting of all 109 felony bail cases passing through the District Attorney's office from March 1 to June 30,1953. See Rule 51C, Rules of Courts of Oyer and Terminer and General Jail Delivery and Quarter Sessions of the Peace of Philadelphia County, 123 LEGAI INTEulxGENCER 671 (Philadelphia, Dec. 21, 1950), for the procedure followed, quoted at note 40 infra.

29. Frd. R. CRIM. P. 46(c). Bail in federal cases can also be set by judges or justices. A sample of 208 federal bail-settings was studied by taking the first 25 cases out of each of the last eight docket books of the United States Commissioner, the cases covering the period from July 5, 1950 to July 2, 1953. Each of these cases was then traced in the records of the clerk of the District Court for the Eastern District of Pennsylvania to determine the outcome of the case and to see if the defendant obtained release on bail.

30. Out of 857 hearings, defense lawyers appeared in 130.

31. PA. SAT. ANn. tit. 42, 1048 (Purdon 1930). The only qualifications for the position are that the magistrate must be at least 35 years old, be a natural born citizen or naturalized for at least ten years, and be a qualified voter of Philadelphia and have been a resident thereof for at least five years. A few of the magistrates are lawyers. 
addition to this evidence, the magistrate has before him the information in the docket: name, address, age, occupation (sometimes omitted) and charge. In some cases he will also have the criminal record, and, in the $15 \%$ of the cases in which defense counsel are present, the magistrate may be given some further information about the defendant relevant to bail determination.

During the hearings, magistrates frequently interject questions and, in about one-third of the cases, various factors which are thought to be relevant to bail will be discussed, such as criminal record, employment, family status, cooperation with the police, value of property taken, or amount of damage done. After all the testimony has been concluded, the magistrate either dismisses the defendant, sets bail for court, or, in cases in which bail can be set only by a judge, holds the suspect "without bail for court." The decisions as to holding the defendant and the amount of bail are given together, and there was little indication that any independent thought had been given to the amount of bail.

Because custom or intuition appears to be the basis of bail determinations, it is difficult to ascertain what standards are being applied. However, the fact that evidence of the crime is the only information which the magistrate possesses in two-thirds of the cases ${ }^{32}$ indicates that the nature of the crime and circumstances behind the particular charge are the primary factors in bail decisions.

Although theoretically the only purpose to be served in determining the amount of bail is to assure the defendant's presence at his trial, it was evident from observation of magistrates' court hearings that this was not the only objective. Chief Magistrate Clothier stated that bail is used to "break" crime waves, ${ }^{33}$ and in many cases the setting of high bail by the magistrates was motivated by a desire to keep the defendant incarcerated until the time of trial. Sometimes, however, a magistrate would exercise restraint and adhere to the theory of bail. When an assistant district attorney asked for $\$ 1500$ bail in one case, the magistrate responded: "Bail is set to insure appearance. We don't punish people by setting high bail." 34 But this example is the exception and normal magisterial practice indicated that bail was often used for punishment purposes. The following reports sustain this conclusion and also show that it is frequently assumed in the hearings, solely on the basis of prosecution testimony, that the defendant is guilty.

In setting bail for an employee accused of larceny by sneak, one magistrate said: "I'll make it $\$ 1500$-that will hold anybody." One could interpret this as an attempt to create an obligation to appear for trial, but the disproportionate amount and the lack of concern for the individual indicate an intent to keep the defendant in jail.

32. In the 124 observed cases, questions relative to bail were not asked in 87 .

33. Interview, June, 1953.

34. This and all succeeding quotations from magistrates were either obtained from the transcripts of the proceedings or were taken down at hearings by the observer for this study. 
One case inspired the magistrate to exclaim: "Anybody that hits their mother with a blackjack, there is sure something wrong, lady." When the assistant district attorney objected to the bail of $\$ 1000$ by saying that $\$ 500$ would be sufficient, the magistrate replied: "I disagree with you, Mr. District Attorney. I feel that the man should be punished and I don't feel that $\$ 500$ bail is sufficient." When the defendant's attorney protested the use of bail as punishment, the magistrate denied such an intention and reduced the bail to $\$ 800$.

In setting $\$ 600$ bail for a numbers offense, the magistrate said: "If you didn't bite the policeman I wouldn't be so hard. I would be lenient with you."

In a case involving an auto offense, the magistrate exclaimed: "All right, I don't like hit and run drivers"; and $\$ 800$ bail was set.

An assault and battery case, in which the victim was hospitalized, prompted bail of $\$ 1,500$ and the explanation: "He is a Puerto Rican. What a bum."

A defendant charged with injuring his father's eye was told: "Anyone who hits his father ought to be electrocuted." $\$ 1500$ bail was set for further hearing.

Another case involved a Negro woman who intervened after a policeman had told a Negro boy to stop grabbing the packages of customers coming out of a supermarket. A heated argument developed into a fracas, and eight police cars responded to a riot call. The magistrate lectured the defendant on minding her own business and said: "I'm going to make an example of you." $\$ 1500$ bail was set.

Another indication of the use of bail for punishment was the practice of ostensibly setting bail for each offense with which the defendant was charged. When a defendant's attorney in one case asked for reduction of bail from $\$ 10,000$, the magistrate said: "Today we have two cases involving two things. I set $\$ 5000$ on each case, or $\$ 10,000$ for court."

For a charge of forgery and false pretenses, bail was set as follows: "On the $\mathrm{M}-\mathrm{A}-$ case, $\$ 1000$; on the $\mathrm{M}-\mathrm{G}-$ case, $\$ 500$; on the other $\mathrm{G}-$ case, $\$ 500$; the $\mathrm{C}$ - case, $\$ 500$; the $\mathrm{S}$ - case, $\$ 500$; the J- G- case, $\$ 500$; the $H-M$ - case, $\$ 500$." The total for this one defendant was $\$ 4000$.

A defendant charged with gambling and assault and battery on an officer was held on $\$ 800$ for each offense, or a total of $\$ 1600$.

Another purpose in setting bail, especially for narcotics cases, was an endeavor to keep the defendant from continuing his practices by incarcerating him in jail. In setting bail for a narcotics and assault and battery offense, one magistrate said: "I'm tired of seeing you in front of me; I'll hold you in $\$ 2500$ bail for court. Maybe that will keep you in for a while." In another case, involving assault and battery on a woman, a police captain recommended: "I would like to ask for a high bail on this fellow. He should be kept off the street and we should protect these women. I would 
ask for $\$ 10,000$ bail." Although the magistrate set $\$ 5000$, this figure is still many times above the standard for assault and battery and sufficiently high to make it very probable that the defendant could not raise bail.

On the other hand, there was a tendency to use low bail when the magistrate felt that the crime was not a serious one, or when he felt that there were mitigating circumstances, or when he was not convinced of the defendant's guilt. In one case, a police officer was charged with driving a police car while intoxicated and bail was first set at $\$ 300$. When informed that the defendant had four children and would be severely handicapped if forced to raise $\$ 300$, the magistrate reduced it to $\$ 100 .{ }^{35}$

Two men were charged with slugging an officer in a case which grew out of the arrest of sidewalk gamblers who had almost been snatched from the hands of the police by a disorderly mob of sympathizers. The defense was that the officer had hit the defendants' mother first. The magistrate, noting that it was Mother's Day, released the defendants in the custody of their mother for a further hearing. ${ }^{36}$

In a case of public indecency, the magistrate said: "This woman is positive. Therefore, I'll have to hold him for court, but I'll make bail very low," i.e., $\$ 300$ for court.

One magistrate reduced bail twice during a hearing (from $\$ 800$ to $\$ 600$ to $\$ 500$ ) when the defendant kept protesting his innocence.

In a case of assault with threat to kill, when the assistant district attorney suggested $\$ 2000$ or $\$ 1500$, the magistrate replied: "I think there are extenuating circumstances," and he set $\$ 1000$ bail.

In a numbers case, a magistrate said: "We'1l be easy on Murphy," and he set $\$ 300$ for court.

The failure to release defendants on their own recognizance in any cases except assault and battery by automobile indicates that magistrates may not be aware of their clear power to release a defendant without security. ${ }^{37}$ In one gambling case, in which the defendant's attorney asked that the defendant be released in the attorney's custody, the magistrate said: "This District Attorney is gunning for me. They're arresting magistrates for things like that."

A few cases were observed in which a defendant should not have been held at all, but the magistrate nevertheless set bail, either to make the defendants "serve some time" for acts for which they could not be convicted or, by finding a prima facie case, to protect the arresting officers against possible false arrest suits. In one case two defendants were alleged to have done nothing more than ask the prosecuting witness for change for $\$ 500$. The magistrate, apparently recognizing a potential confidence scheme, held each in $\$ 600$ bail. The defendants could not raise the money and thus each spent a month in jail. In an assault and battery case, the

35. Philadelphia Inquirer, May 10, 1954, p. 1, col. 4.

36. Id., p. 1, col. 1.

37. McNair's Petition, 342 Pa. 48, 187 Atl. 498 (1936). 
magistrate held the defendant in $\$ 300$ bail because "I want to protect the officer so they cannot do anything to you [the officer]."

On other occasions, gamblers were brought in by detectives with no evidence. The detectives had been ordered to arrest "known gamblers" whenever possible to get them to leave the district. ${ }^{38}$ The magistrates dismissed the charges in these cases and issued stern lectures to the police on citizens' rights.

Except for narcotics offenses, the amount of bail set by the magistrates was usually under $\$ 1000$. The usual figures were $\$ 300, \$ 400, \$ 500, \$ 600$ or $\$ 800$, with gambling offenses averaging $\$ 500$ and narcotics $\$ 1250$. One of the greatest ranges occurred in assault and battery, in which the amount varied from $\$ 300$ to $\$ 5000$. Of 100 assault and battery cases in the District Attorney's pre-indictment file between June 26 and July 13, 1953, the distribution of bail was: $\$ 300-13 ; \$ 400-7 ; \$ 500-29 ; \$ 600-16 ; \$ 700-$ $1 ; \$ 800-11 ; \$ 1000-13 ; \$ 1500-3 ; \$ 2000-2 ; \$ 2500-2 ; \$ 5000-3$.

For 81 untaxed liquor cases in a sample taken from the same source the range was smaller, 21 being under $\$ 500,39$ at $\$ 500,20$ between $\$ 600$ and $\$ 1000$, and one at $\$ 1500$.

The amount of bail for each crime depended, furthermore, on the particular magistrate before whom the defendant appeared, for each magistrate develops his own intuitive pattern. In a sample of 226 hearings for gambling offenses the average bail for all cases was $\$ 503$, but the averages for some individual magistrates ranged from $\$ 382$ to $\$ 610$ :

$\begin{array}{cccccccc}\text { Magistrate } & \$ 300 & \$ 400 & \$ 500 & \$ 600 & \$ 800 & \$ 1000 & \text { Average } \\ \text { A } & 0 & 4 & 15 & 14 & 5 & 1 & \$ 600 \\ \text { B } & 1 & 1 & 10 & 0 & 0 & 0 & \$ 475 \\ \text { C } & 8 & 2 & 11 & 0 & 0 & 0 & \$ 413 \\ \text { D } & 6 & 3 & 7 & 10 & 10 & 0 & \$ 610 \\ \text { E } & 4 & 12 & 1 & 0 & 0 & 0 & \$ 382 \\ \text { All magistrates } 44 & 39 & 81 & 30 & 28 & 4 & \$ 503^{39}\end{array}$

Thus Magistrate D imposed an amount more than $\$ 500$ in $59 \%$ of his cases, while Magistrate $\mathrm{E}$ never imposed more than $\$ 500$ and was below that figure in $94 \%$ of his cases.

The more serious state offenses are not bailable by a magistrate and bail can be set only if the defendant through his attorney requests such action by the Quarter Sessions Court. ${ }^{40}$ In such instances, a copy of the

38. See, e.g., Philadelphia Evening Bulletin, October 19, 1953, p. 1, col. 4; Philadelphia Inquirer, October $20,1953, \mathrm{p} .1$, col. 2 .

39. This total includes the individual magistrates shown in the table.

40. See note 28 supra. Rule 51C, Philadelphia Quarter Sessions Court, see note 28 supra, provides: "Informal oral applications for fixing bail without issuing a writ of habeas corpus or requiring the appearance of the Commonwealth's witnesses may be made in Quarter Sessions Courtroom No. 2, at 10 a.m. on any day following commitment, provided 24 hours' notice of intention to do so has been given to the district attorney and to the Bureat of Police. On such application only the police report need be considered in determining whether bail shall be allowed, and neither the defendant nor the prosecuting witnesses need personally appear. Only one such informal application may be made." 
commitment sheet is brought to the District Attorney, who adds a resumé of the facts and a recommendation as to bail. The courts followed this recommendation in $95 \%$ of the cases, so that the District Attorney was actually the one who made the bail determination. An office list of recommended bail for each offense is utilized by the assistant district attorney in making the recommendation. Selections from this list follow:

"Consider always: Has he a family; a job; a house he owns; a record? And is there publicity of the sort to make him run? Also, what is the value of property or money taken?

"Sodomy: $\$ 750$ normal where defendant's partner adult. Upward where (a) partner a minor; (b) violence.

"Burglary: (a) Of building- $\$ 1500$ normal. Upward where felony intended to be committed inside was other than larceny; upward where weapon carried. (b) Of auto- $\$ 500$ normal.

"Robbery: (a) Strong Arm-\$1500 normal. (b) Knife or Gun -\$2500 normal.

"Rape: (a) Other than what would have been Common Law$\$ 500$ normal; upward where girl 13 or younger. (b) Common Law$\$ 2500$, upward where injury other than the rape itself is caused.

"Arson: $\$ 1000$ normal.

"Bad Checks: $\$ 2000$ normal; these fellows wander."

In $37 \%$ of the cases, the individual recommendation was lower in multiples of $\$ 500$ than the listed figure for the crime, and in $19 \%$ of the cases it was higher.11 The factors which caused such variations are not clear, but apparently they include lack of evidence or a large family on the one hand, and a bad criminal record or particularly heinous act on the other. ${ }^{42}$

In federal cases, the procedure for bail determination before the United States Commissioner was far more dignified than were the comparable state proceedings. The low volume of cases, the fact that the proceedings take place in the Federal Court House, the lack of trials for summary offenses, the absence of noise and confusion, and the high calibre of the personnel all contributed to this difference. The assistant United States attorney handling a particular case is expected to recommend bail; but there is no list comparable to the recommended bail list of the District Attorney's office, and apparently little thought is given to the problem of amount of bail in the United States Attorney's office. The Commissioner considered primarily the severity of the crime but in most cases it appeared that he also took other relevant factors into account.

41. Based on a sample of 122 felony bail cases passing through the District Attorney's office from March 1, 1953 to June 30, 1953.

42. Rape in particular rarely received as much as its listed $\$ 2500$ bail. Fifteen out of seventeen cases were lower, one was $\$ 2500$ and one $\$ 5000$. 
Of 208 bail settings at the Commissioner's hearings, 121 , or $58 \%$, resulted in the release of the defendant before trial. Fifty of those released were allowed to sign their own recognizances. Nearly half of these 50 defendants were charged with failure to report for induction under Selective Service, and all but one of their cases were dismissed when they reported for induction. Excluding these special Selective Service cases, the number obtaining release was $52 \% .{ }^{43}$ The average amount set for those raising bail (excluding the recognizances) was $\$ 1200$; for those remaining in jail the average bail was $\$ 2800$. Highest bail was for narcotics offenses, averaging $\$ 3600$ for 51 cases, or nearly three times the average state bail for the same offense. This discrepancy suggests the arbitrary determination of the standard against which individual bail is measured. The different and sometimes interstate nature of federal crimes hardly warrants establishing a standard which is several times higher than that set for state offenses.

Bail determinations made in federal cases, by magistrates, and in Quarter Sessions Court all display, the great emphasis placed upon the nature of the offense in fixing the amount of bail. Particularly in state cases, there was seldom any explicit examination of the factors which are relevant to the likelihood that the individual defendant is a good or a poor risk. Frequently the imposition of high bail was unrelated to this risk. Rule 51C of the Quarter Sessions Court, governing bail fixing in that court, explicitly provides that "on such application only the police report need be considered in determining whether bail shall be allowed, and neither the defendant nor the prosecuting witnesses need personally appear." 44 This removes any possibility of making the kind of determination which appellate courts have held to be required.45

Custom has established a standard related to the nature of the crime charged, a standard which is sufficiently flexible to permit in any crime an amount sufficient to have the practical effect of holding most defendants in prison. The individual is subordinated to the class into which he is placed according to the type of crime with which he is charged, although what relationship to the risk of non-appearance this may have is unknown.

\section{(c) Time Necessary to Obtain Bail}

The effectiveness of the right to bail is partly dependent upon the speed with which it can be exercised. Two questions are involved: (1) the extent of police detention before the preliminary hearing and (2), the delay in setting bail in cases in which the magistrate is not authorized to perform that function.

The first question does not raise a serious problem in Philadelphia at the present time. The District Attorney's office, with the cooperation of

43. Compare proportion of defendants released in state cases. See note 68 infra.

44. See notes 28,40 supra.

45. See notes 2,11 supra. 
the police, is currently enforcing a rule providing that persons arrested before $8 \mathrm{a} . \mathrm{m}$. are brought before the next regular sitting of the magistrates' court at 9 a.m. so that no detention can exceed 25 hours. ${ }^{48}$ During the period of detention prior to the preliminary hearing, persons arrested for some lesser offenses may obtain release overnight on a copy of the charge. ${ }^{47}$ The officer in charge of the police station in which a defendant is held must, upon request, issue a copy of the charge against the defendant. ${ }^{48}$ If the defendant's representative can find a magistrate and persuade him to sign the copy, the prisoner is released until the preliminary hearing.

In the sample which was studied, 348 defendants, or approximately one out of five, obtained release in this manner, and only four failed to appear at the hearing the next day. It was impossible to observe what standards the magistrates applied in their administration of release on the copy of the charge, because their decisions are made at all hours wherever a magistrate can be found.

A much more serious procedural problem is created by the division of responsibility for setting bail, prohibiting the magistrate from setting bail for persons accused of arson, rape, mayhem, sodomy, buggery, robbery or burglary. ${ }^{49}$ Persons charged with these offenses, after being held at the preliminary hearing, must procure someone else (usually an attorney) to notify the District Attorney that bail is requested; he must then have the District Attorney's recommendation placed on the commitment sheet and have a common pleas judge sign the order for bail. ${ }^{50}$

The practical effects of this procedure were twofold. First, for those who obtained bail it took an average of five days from the time of the preliminary hearing until bail could be posted. ${ }^{51}$ This period is almost five times as long as the average time required when bail was set in magistrates' court.52 Second, the procedure frequently operated to deny bail, notwithstanding the constitutional mandate that all offenders charged with

46. Anjual Report 1952, District Attorney's Office of Philadelphia 10 (1953) (hereinafter cited as DrST. ATT'y REP.). Note, however, the possibility of further detention in a case in which a magistrate continues a preliminary hearing for a defendant for whom the magistrate cannot set bail. This increases the delay discussed in text at note 49 et seq. infra.

47. Pa. Stat. Ann. tit. 42, §1113 (Purdon Supp. 1953).

48. Ibid.

49. Pa. Stat. AnN. tit. 19, § 51 (Purdon Supp. 1953).

50. This was the procedure normally followed when this study was made, rather than the more formalized method prescribed by Quarter Sessions Court Rule 51C, quoted at note 40 supra.

51. Based on 75 cases for which data could be obtained from the same sample described in note 28 supra.

52. Out of 368 persons who obtained bail after it had been set by a magistrate in preliminary hearing, based on a sample of all cases entering the District Attorney's pre-indictment file between July 15 and August 11, 1953, the time required for release on bail was:

297 defendants were released the same day as the preliminary hearing;

24 were released the day following the preliminary hearing;

47 defendants were released later than the day after the preliminary hearing, the average time for these 47 cases being 7 days after the preliminary hearing. 
non-capital offenses "shall be bailable." ${ }^{53}$ In common parlance among police and magistrates the crimes for which the latter cannot set bail are described as "non-bailable," and there is ironic truth in this label. When a magistrate holds such an offender at preliminary hearing, he will state, "without bail for court," and a substantial number of defendants do not - understand that they may still be able to obtain bail by going through the procedure outlined above. Among the prisoners interviewed during this study who were being held in jail awaiting trial, 46 were defendants being "held without bail." Thirty-two of these, or 70\%, stated that they had not learned of the possibility that they could obtain bail until they had been in prison for some time. A number did not learn of their rights until they talked with us or with a representative of the Philadelphia Voluntary Defender Association, or until they found out by prison rumor after a week or two in jail.

Sometimes the officials foster this fiction. In one case in which a seaman was held "without bail for court" the following exchange took place:

Defendant: "What do you mean, hold me without bail"?

Magistrate: "That means that you will be kept in jail for two or three weeks until this case can be decided by a higher court."

Defendant: "You mean I got to stay here all that time"?

Magistrate: "Are you kicking? Why, lots of guys jump ship just so they can stay here."

One of the prisoners stated that his mother asked a detective how much bail was required, and was told only that the defendant was being held without bail.

Even those who are aware of their right to apply to the court for bail must surmount the obstacles and delay inherent in the requirement of a second hearing. It is virtually essential for a defendant to obtain an attorney before he can proceed to have bail set, and this involves both delay and expense. The District Attorney's office has recently announced a policy which will increase the delay in robbery cases. According to this report: 54

"It was understood that [Chief Inspector] DuBois, acting for Police Commissioner Thomas J. Gibbons, suggested that the district attorney's office make bail for armed holdup so high that the defendant would be forced to remain in jail until trial.

"The bail in such cases, fixed by the court after a magistrate's hearing, now averages $\$ 2500$. It was reported that even at this figure not one in ten armed holdup suspects is able to raise bail.

"While the district attorney's office rejected the suggestion of higher bail in such cases, it agreed to ask the court to follow stricter procedure in fixing the bail.

53. See note 1 supra.

54. Philadelphia Evening Bulletin, Jan. 21, 1954, p. 3, col. 1. This procedure follows that outlined in Rule 51C rather than the more informal method normally employed. See text at note 50 supra. 
". . . in the future the defendant will have to give 24 hour formal notice in writing to the district attorney's office and the police of his intention to ask for bail. Then an assistant district attorney and detectives will appear before the court when bail is asked."

The division of responsibility, which makes possible such infringements of the right to prompt bail, is an anachronism which has no practical utility. When the court sets bail in the "non-bailable" offenses it almost invariably follows the recommendation of the District Attorney. The latter is also represented at preliminary hearings, and there is no reason why bail in all cases should not be set at that time, provided that the District Attorney has the right to petition a court immediately for higher bail if he feels that the amount set is too low:55 In the absence of legislative change to this end, the spirit of the constitutional guarantee would demand that each defendant be fully informed at the preliminary hearing of his right to bail, and that in all cases bail be set promptly by the court without requiring that the defendant, handicapped by his incarceration in prison, first obtain a lawyer and make a formal request.

\section{(d) Effecting Release on Bail}

A defendant, for whom bail has been set in an amount which he is financially able to afford, faces problems arising out of his relationship with bondsmen or the inadequacy of facilities for posting bail. A recent Pennsylvania statute regulating professional bondsmen limits the amount which they can charge to not more than $10 \%$ on the first $\$ 100$ and $5 \%$ on each additional $\$ 100.56$ In the event of an overcharge, the Act provides for treble damages ${ }^{57}$ and for a fine and imprisonment. ${ }^{58}$ The Act also seeks to prevent gouging by making it a misdemeanor for any person to accept "any fee or compensation for obtaining a bondsman" ${ }^{59}$ or for "any

55. Senate Bill No. 472, Session of 1953, Pennsylvania legislature, which failed to pass, would have provided that for offenses for which the magistrate is not now able to set bail, see PA. STAт. ANN. tit. 19, § 51 (Purdon Supp. 1953), the magistrate shall set bail. "If the district attorney at the hearing before the mayor magistrate alderman or justice of the peace objects to the amount of bail fixed or the surety or sureties required if any the accused shall not be discharged but shall be brought before a law judge of a common pleas court within forty-eight (48) hours for the purpose of the fixing of bail by that court."

56. Pa. Stat. ANn. tit. 19, $\$ 90.9$ (Purdon Supp. 1953).

57. Ibid.

58. Id. $\$ 90.10$ (b) (fine of $\$ 500$ to $\$ 1000$ and/or imprisonment not exceeding six months). For a similar provision, see ILL. ANn. STAT. c. 38, \$627(n) (Smith-Hurd Cum. Supp. 1953). See also MoNTGomery, Report of THE Clerk of the Recorder's Court, CITY of Detrorr 16, 35 (1952), reporting maximum rates in effect in Washington and Baltimore ( $5 \%)$ and Boston ( $5 \%$ on secured bail and $10 \%$ on unsecured). The average fees in Detroit are reported to be the same as in Boston, but there is no legal control over the fee. "We have approximately fourteen licensed bail bondsmen and the competition between them is keen. This competition serves as a control over the amount of fees charged." Letter dated November 17, 1953 from E. Burke Montgomery, Clerk of the Recorder's Court, Detroit, on file in Biddle Law Library, University of Pennsylvania Law School.

59. Pa. Stat. Ann. tit. 19, $\$ 90.10$ (c) (Purdon Supp. 1953). 
law enforcement officer, employe of a penal institution," or court official to have a pecuniary interest in or derive any profit from the bonding business. ${ }^{60}$

Such limitations have not proved to be very successful in preventing overcharging in other jurisdictions. ${ }^{61}$ In Philadelphia in 1952 an investigation by the District Attorney's office "revealed that defendants involved in morals charges and in charges of driving motor vehicles while intoxicated were particularly susceptible to being shaken down by bondsmen," and two arrests resulted. ${ }^{62}$

A related problem in other jurisdictions, about which we have no Philadelphia information, involves collusion between lawyers and bondsmen. In Chicago, "aside from the question of ethics in having bondsmen solicit cases for lawyers and the 'pressuring' of the accused into accepting the attorney of the bondsmen's choice, there is unquestionably in such instances a splitting of fees between the attorney and the bondsmen so that in most instances the accused does not get the best representation for his money." ${ }^{3}$ In New York the Kings County Grand Jury found that bondsmen were recommending lawyers, splitting fees and, in some cases, refusing to furnish bail unless those lawyers were chosen. ${ }^{64}$

The final procedural provision, which is necessary to facilitate the release of defendants able to post bail, is the existence of convenient facilities for this purpose. In Philadelphia, bail may be posted before any magistrate, and the office of the bail clerk of Quarter Sessions Court is open during normal business hours. The Magistrate's Court Act requires that a magistrate be available 24 hours a day at the Central Police Station, but at the time of this study this provision was ignored. ${ }^{65}$ Compliance with the law in this respect would be of substantial benefit both in facilitating the posting of bail and in obtaining the necessary signature for release on a copy of the charge. It also would do away with the necessity of searching for a magistrate and perhaps waking him up in the middle of the night to take bail.

60. Id. $\$ 90.10(\mathrm{e})$.

61. "Probably the two most prevalent evils still existing [regarding bail] and for which there appear to be no satisfactory solution despite close supervision and the records which the bondsmen are required to keep by law or established rule are: (1) Fees charged in excess of the statutory limit and (2) solicitation of cases on behalf of attorneys by bondsmen." Letter dated March 2, 1953 from V. W. Peterson, Operating Director, Chicago Crime Commission, on file in Biddle Law Library. See also MONTGOMERY, REPORT, op. cit. supra note 58 at 16, 22, for a report that the maximum fee rule is probably not observed in Baltimore and Washington.

62. Dist. ATr'y REP., op. cit. supra note 46 , at 14 .

63. Letter from V. W. Peterson, supra note 61.

64. New York Times, March 9, 1948, p. 26, col. 3. For other instances of collusion see MONTGOMERY, Report, op. cit. supra note 58 at $4,16$.

65. "There shall be established a magistrates' court in the city hall of the city of Philadelphia which shall be open during the entire twenty-four hours of each day, with a magistrate continually present thereat or immediately available. . ." PA. Stat. AnN. tit. 19, \$1110 (Purdon Supp. 1953). 


\section{The Jailed Defendant}

One evil of a system which employs the financial deterrent of a bond as its method of compelling appearance in court is its effect upon those who are unable to post the bond. The right to bail is founded upon the belief that it will not only help keep the innocent from being punished while awaiting vindication but that it will also enable the defendant to work with his counsel, search out evidence and witnesses in preparation of a defense, and maintain employment so that he can support his dependents and employ the counsel of his choice. To determine the extent to which the Philadelphia bail system effectuates this policy, investigations were made to determine (1) what proportion of defendants do not raise bail and are detained from arrest until trial; (2) what proportion of such jail defendants are found innocent and what proportion of those who are found guilty are not sentenced to imprisonment; (3) the duration of such pretrial detention; (4) the possible prejudices to the jail defendants compared with bail defendants in trial and sentencing; and (5) the extent of the handicap of having to prepare a defense from a prison cell. ${ }^{66}$

\section{(a) Proportion of Defendants Detained}

Three out of four defendants charged with serious crimes for which bail must be set in court ${ }^{67}$ were held in jail between arrest and trial. Of those charged with less serious crimes for whom bail was set by a magistrate, about one in four $(27 \%)$ did not obtain release. These figures are based on samples totaling 752 defendants who were being held for trial during the summer of 1953.68 This shows that the practical effect of Philadelphia methods for determining the amount of bail is to deny bail to the great majority of those charged with more serious offenses and to a substantial proportion of those charged with lesser crimes. It explains the chronic overcrowding in the untried department of the County Prison,

66. These facts were obtained for state cases only, and no comparable studies were made of federal cases. As federal prisoners awaiting trial are held in the same prison as state untried prisoners, conclusions drawn about the effects of imprisonment upon preparation of a defense are equally applicable to them. See ANNUAL REPORT 1952, Philadelphia County Prison BoARd of Inspecrors 31 (1953) (hereinafter cited as Prison Rep.).

67. Arson, rape, mayhem, sodomy, buggery, robbery or burglary. PA. Stat. ANN. tit. 19, $\$ 51$ (Purdon Supp. 1953).

68. The sample for defendants whose bail was set by magistrates' court consisted of all cases in the District Attorney's pre-indictment file between July 15 and August 11, 1953; out of a total of 501 defendants, 368 obtained bail and 133 did not. Statistics for defendants held for the more serious crimes, see note 67 supra, were more difficult to obtain, and were compiled in the following way. The dockets at Moyamensing Prison (the county prison) show that 251 defendants were committed pending trial for these offenses during May and June, 1953. The number of defendants for whom bail was set by Quarter Sessions Court and who raised bail during the same months is estimated at 62 . This total was compiled by checking all cases in which the District Attorney recommended bail under the informal procedure described at note 50 supra against bail records in the offices of the Clerk of the Court of Common Pleas and the Bail Clerk of Quarter Sessions Court. This search indicated that 46 defendants raised bail, and to this was added 16, an estimate for the defendants whose bail was set under the procedure provided by Quarter Sessions Court Rule 51C, see note 40 supra. This estimate was based on the opinion of Stanley Bashman, Chief of the Bail Division, District Attorney's Office. 
where in 1952 detainees spent a total of 131,683 days awaiting trial. ${ }^{69}$ That such a large volume of defendants are jailed pending trial emphasizes the importance of examining what disposition is made of their cases and the effects of imprisonment upon those dispositions.

\section{(b) Disposition of Jail Cases}

Most Philadelphia cases are brought to court for disposition. The practice of the District Attorney's office is to seek indictments in all cases in which the accused are held at preliminary hearing, and the grand jury, which acted on 17,168 cases in 1952, "is too overburdened to discriminate in any great number of cases." 70 During 1952 only 735 bills were ignored by the grand jury, which means that only about $4 \%$ of all cases were disposed of by failure to indict. ${ }^{71}$

A study of the disposition of 1000 jail cases showed that the defendants fell into three major categories: ${ }^{72}$

(1) Forty-seven per cent of all jail defendants were convicted and sentenced to a term of imprisonment. As they received credit on their sentences for time served while awaiting trial, they lost nothing in terms of confinement by not posting bail.

(2) A second group (318 defendants) were convicted but did not have to serve any time in prison after conviction. Of these, 228 were either fined or given suspended sentences. Failure to raise bail penalized these defendants, in comparison to comparable offenders who did raise bail, in that they served jail terms ${ }^{73}$ only because of their poverty. The remaining 90 of this group were sentenced to the period of time which they had already served while awaiting trial, and they were released im-

69. See Prison REP., op. cit. supra note 66 , at 31 .

70. Dist. ATr'y REP., op. cit. supra note 46 , at 12 .

71. Ibid.

72. This sample consists of 958 jail cases which were disposed of by Quarter Sessions Court between August 15 and December 31, 1953, to which was added 42 cases to make allowance for the fact that four and a quarter per cent of all cases held at preliminary hearings are disposed of because the grand jury ignores the bill. See DIST. ATT'Y REP., op. cit. supra note 46, at 12 . The sample includes all cases for all offenses during the period studied, and is broken down as follows:

$\begin{array}{lr}\text { Not indicted } & 42 \text { (est.) } \\ \text { Nolle Prosequi } & 30 \\ \text { Demurrer to evidence sustained } & 21 \\ \text { Acquitted } & 117 \\ \text { Suspended Sentence } & 193 \\ \text { Fine } & 35 \\ \text { Sentenced to time already served } & 90 \\ \text { awaiting trial } & 972\end{array}$

Compare the dispositions of 2077 "finished cases" handled by the Voluntary Defender in Quarter Sessions Court for the 12 months ending June 1, 1953. Of these, $29 \%$ were not convicted, consisting of 397 acquittals and 205 otherwise not convicted, and $21 \%$ were given suspended sentences or probation. The remaining $50 \%$ were sentenced to imprisonment. See Nineteenth AnNual Report, Philadelphia Voluntary DeFENDER ASS'N 1952-1953 at 10 (1953) (hereinafter VOL. DEFENDER REP.):

73. Some of those fined may subsequently serve a further term in prison in lieu of fine and costs. A total of 137 prisoners in this category were received by the County Prison in 1952. See PrISON REP., op. cit. supra note 66, Table 6 at 40. 
mediately after conviction. It is impossible to determine whether these defendants would have been sentenced to a comparable short term, if they had been out on bail; but, since they were released immediately, the judgment might merely be an acknowledgment that the defendants had already served the time and that if they had been out on bail, they might have received suspended sentences. This explanation seems especially valid in light of the apparent discrimination between the treatment of jail and bail cases, ${ }^{74}$ and therefore for the purposes of this study sentences to time already served are regarded as equivalent to suspended sentences.

(3) One out of five jail defendants was not convicted. Nearly twothirds of these were acquitted and the remainder were dismissed on nolle prosequi, demurrer to the evidence, or failure to indict. These 210 defendants were required to serve a jail term although they were innocent.

A sample of 181 defendants charged with burglary and serious violent crimes ${ }^{75}$ revealed no significant variation in these figures for the more serious offenses. Of these defendants, most of whom have only one chance in four of pre-trial release on bail, 24\% were not convicted, $27 \%$ were not sentenced to further imprisonment, and $49 \%$ were imprisoned.

\section{(c) Duration of Pre-trial Detention}

The interviewed prisoners, whose cases were followed to their termination, served an average of 33 days between preliminary hearing and disposition. The distribution according to duration of detention is shown in figure $3 .^{76}$

The longest detentions for those who ultimately were not convicted were 75 days for a defendant whose case was nol prossed, 60 days for a man acquitted on a charge of carrying a concealed deadly weapon, and 56 days for a person acquitted of robbery. The shortest detention was 13 days for a defendant acquitted on a liquor charge.

The maximum period of pre-trial detention is limited in Pennsylvania by the requirement that a defendant who is held in jail shall be discharged from imprisonment if he "shall not be indicted and tried the second term, session or court after his or her commitment . . ." 77 A limitation which

\section{See text at note 84 infra.}

75. Rape, robbery, arson and aggravated assault and battery. The sample consisted of jail dispositions for the months of October and November, 1953.

76. The sample on which this is based consists of only 83 cases. Compare the "crude average number of days" served in Moyamensing Prison by all prisoners awaiting trial in 1952, which was 37 days. This average includes defendants who spend a few days in prison and then are released on bail, so that the average detention for defendants who never make bail would be longer. See PRISON REP., op. cit. supra note 66 , Table 4 at 38 . This may indicate that our sample shows too short a period of detention. See, however, an estimate that by 1953 "the average stay of those untried has been reduced to three to five weeks." Id. at 90 .

77. Pa. Stat. AnN. tit. 19, 781 (Purdon 1930). 
TIME SPENT IN JAIL AWAITING TRIAL

$\%$

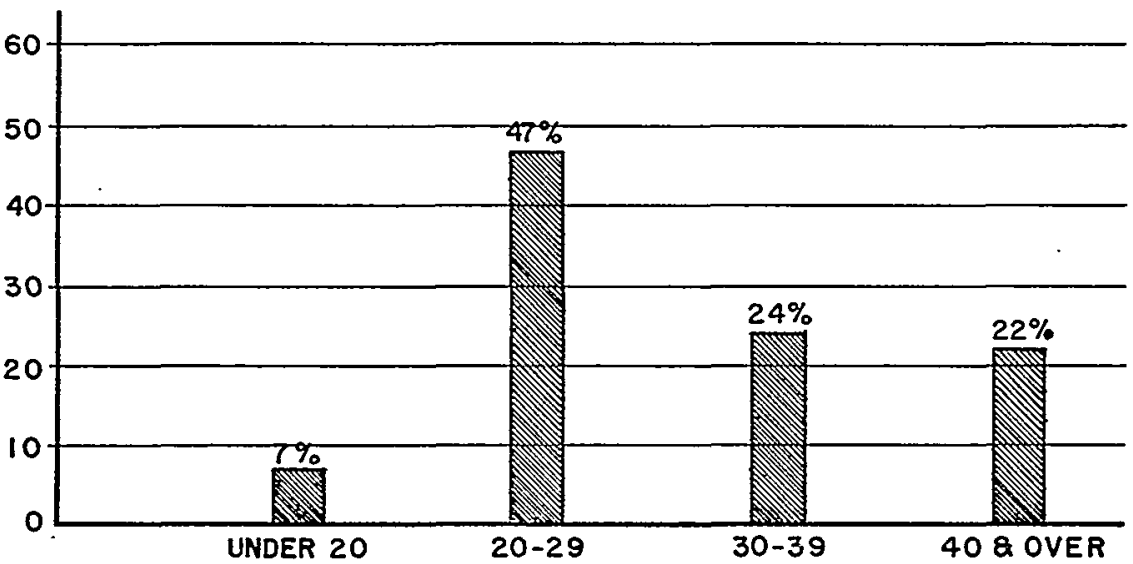

Figure 3. Distribution of Defendants According to Number of Days Spent in Jail Awaiting Trial

in Philadelphia is of more practical importance is the policy inaugurated at the request of the Voluntary Defender whereby any detainee who is not indicted by the Grand Jury within 20 days will be brought into court so that a judge may consider the advisability of releasing him to await trial without formal entry of bail. ${ }^{78}$

\section{(d) Comparative Treatment}

The disposition of 946 cases was studied to compare the treatment of jail and bail cases. This sample consisted of all dispositions during October and November, 1953, for cases in which the defendants were charged with rape, robbery, arson, burglary, assault and battery (simple and aggravated), auto theft, other property crimes, sex offenses (except rape and prostitution), and narcotics offenses. ${ }^{79}$

This comparison showed that defendants who came to court from jail received much less favorable treatment as to both the proportions of those convicted and those receiving prison sentences. While the many factors involved in determining the disposition of criminal cases require that these statistics be regarded with caution, the contrast between the disposition of jail and bail cases was so striking that it raises a strong inference that the handicap of jail status is a major contributing cause for the difference.

78. See Vol. DefENder ReP., op. cit. supra note 72, at 3.

79. These offenses comprise the great bulk of jail defendants. Defendants charged with other crimes were eliminated because the number of jail defendants was too small to have any validity for comparison with bail cases. 
Although there are marked variations among different types of crimes, table 1 illustrates that a defendant who is out on bail is much more likely not to be convicted than is a defendant who comes to court from jail.

\section{Table 1-Percentages of Indicted Defendants Not Convicted}

\begin{tabular}{|c|c|c|c|c|c|c|}
\hline \multirow[b]{2}{*}{ Crime } & \multicolumn{3}{|c|}{ Defendants on Bail } & \multicolumn{3}{|c|}{ Defendants in Jail } \\
\hline & convicter & $\begin{array}{c}\text { not } \\
\text { convicted }\end{array}$ & $\begin{array}{c}\% \\
\text { not } \\
\text { convicted }\end{array}$ & convicted & $\begin{array}{c}\text { not } \\
\text { convicted } \\
\text { ? }\end{array}$ & $\begin{array}{c}\% \\
\text { not } \\
\text { convicted }\end{array}$ \\
\hline Violent crimes & 50 & 101 & $67 \%$ & 86 & 29 & $25 \%$ \\
\hline Burglary & 19 & 3 & $14 \%$ & 52 & 14 & $21 \%$ \\
\hline Assault and Battery & y 62 & 79 & $56 \%$ & 27 & 7 & $21 \%$ \\
\hline Auto theft & 24 & 8 & $25 \%$ & 33 & 12 & $27 \%$ \\
\hline Property crimes & 47 & 46 & $49 \%$ & 75 & 6 & $7 \%$ \\
\hline Sex crimes & 44 & 16 & $27 \%$ & 11 & 4 & $27 \%$ \\
\hline Narcotics offenses & 29 & 1 & $3 \%$ & 56 & 5 & $8 \%$ \\
\hline All above offenses & 275 & 254 & $48 \%$ & 340 & 77 & $18 \%$ \\
\hline
\end{tabular}

One of the primary reasons for this difference is the much higher proportion of nol prosses in the bail cases. Only ten out of 417 jail case indictments were nol prossed, or $2.4 \%$, whereas there were 160 nol prosses in bail cases, or $30.2 \%$ of all bail indictments. There are at least two explanations for this markedly lower incidence of nol prosses in jail cases which should be given considerable weight. First, the jail defendant is probably unable to obtain the private settlement in lieu of prosecution which Pennsylvania law provides for minor offenses ${ }^{80}$ and is unable to persuade the prosecuting witness or private prosecutor ${ }^{81}$ to abandon the case. Second, while jail cases came to trial in about a month after preliminary hearing, ${ }^{82}$ the time required to bring a bail case to trial was nine months. ${ }^{83}$ Some nol prosses, therefore, may simply mean that the failure to provide a speedy trial has resulted in the loss of valuable evidence. However, even when the nol prosse cases are eliminated, $25 \%$ of bail defendants who went to trial were not convicted, while jail defendants were not convicted in only $16.5 \%$ of the cases.

80. Pa. Stat. Ann. tit. 19, $\$ 491$ (Purdon Supp. 1953). See discussion in text at note 100 infra.

81. The common-law rule whereby a private person can initiate criminal prosecution exists in Pennsylvania. Sadler, Crtarnal Procedure in Pennsylvania \&73. (1937).

82. See note 76 supra.

83. "On the average [bail cases] have to wait nine months before they are tried. Some, we try to speed up. . . Numbers cases are down to a four month wait and narcotics to two.". First Assistant District Attorney Michael von Moschzisker, quoted in the Philadeiphia Inquirer, Feb. 1954, p. 7, col. 4. 
Table 2-Percentages of Convicted Offenders Who Received Prison Sentences

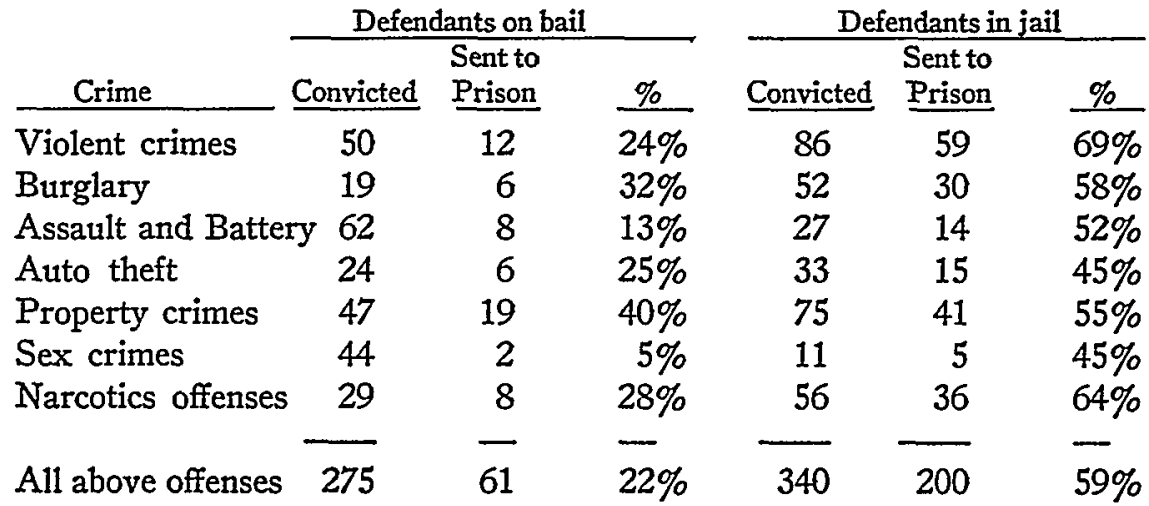

Table 2 shows a comparison of the proportion of convicted offenders, who were on bail and were sentenced to imprisonment, with jail defendants who received a sentence of imprisonment in addition to a sentence imposed for time already served. ${ }^{84}$ Over two and one-half times as many jail defendants got prison terms as is the case for defendants who were out on bail.

A number of factors might contribute to this difference. If the jail defendant had a job when he was arrested, he will have lost it and probably cannot get it back, whereas the defendant who is on bail can usually make the argument that probation will enable him to continue working on a job he then holds. The fact that most jail defendants are represented by the Philadelphia Voluntary Defender may also be significant, for this types the defendant as a man who is already a charity case and a burden upon society, ${ }^{85}$ with the result that the court may be much more inclined to impose a prison sentence. The large volume of cases handled by the small staff of the Voluntary Defender, which limits the effort which can be expended on an individual case, and the fact that the defendant has been isolated in jail and cannot help himself, may also mean that the jail defendant is much less likely to have character witnesses who will appear to urge mitigation of penalty. Such circumstances help explain the inference raised by these statistics that, unconsciously or not, jail status prejudices the courts as to the treatment they prescribe.

The validity of using these statistics for the purpose of showing such prejudice against jail defendants depends upon the strength of other factors which could also account for differences in treatment. It is believed that variances attributable to divergent judicial methods and philosophies were

84. See text following note 73 supra.

85. The Voluntary Defender will represent only those "who, by reason of their poverty, are unable to pay counsel fees." VoL. DEFENDER REP., op. cit. supra note 72 , at 1 . 
largely eliminated because the cases were decided by many different judges. There are other variables, however, which cannot be resolved. For example, if the magistrates are sufficiently sagacious to impose high bail predominantly upon those who are in fact guilty and are lenient with those who are in fact not guilty, then to that extent the higher proportion among jail defendants of those adjudged guilty will not reflect any handicap resulting from jail status. The fact that some magistrates penalize what they regard as aggravated circumstances by setting higher bail may concentrate the aggravated cases in jail and thus partially explain the more severe punishment of the guilty offenders in the jail group. One distinction between the jail group and the bail group is the comparatively lower economic status of the former. This factor would also explain in part the different treatment of these two groups, if in fact indigent persons charged with crime are more likely to be found guilty than all individuals so charged, and if in fact the indigent guilty tend to commit offenses under more aggravating circumstances than do guilty persons in general.

Despite these unmeasurable variables, however, the contrast in comparative dispositions was so striking that it is reasonable to conclude that jail status had a good deal to do with it. Wigmore has noted that any criminal defendant is under the handicap that he looks guilty, ${ }^{86}$ and this applies most forcefully to the defendant who arrives in court in custody from jail where he has had little opportunity to prepare himself so that he can come to trial neat and clean. The following analysis of the conditions under which a jail defendant must prepare for his day in court strongly supports the inference of prejudice raised by these statistics on comparative dispositions.

\section{(e) The Effects of Detention}

Assuming for the moment that pre-trial imprisonment of such a large number of defendants is a necessity, it follows that such imprisonment should impose as few restrictions as is practicably possible which will interfere with a defendant's attempts to get bail and preparation of his defense. This study uncovered serious problems created by the failure to attempt such minimization of the sacrifice which results from imprisonment.

The period of police detention which occurs after arrest but before the preliminary hearing is regulated by the Magistrates' Court Act. ${ }^{87}$ This statute, which is applicable only to Philadelphia, requires that "all persons arrested shall be given the opportunity to promptly communicate with, be interviewed or examined by, such persons as they desire." 88 It is difficult to determine how well this requirement is observed. Several of the interviewed prisoners stated that they were not allowed to telephone anyone, and one stated that police policy denied access to the phone for everyone

86. 9 Wigmore, Evidence $\$ 2511$ (3rd ed. 1940).

87. PA. Stat. Anw. tit. 42, $\$ 1101$ et seq. (Purdon Supp. 1953).

88. Id. $\S 1113$. 
who was arrested and confined in the station house with him. It is probable that Negro or poorly-dressed defendants are frequent victims of such violations. That even some well-dressed and apparently reliable defendants lose their right to outside communication is indicated by a report from a Quaker defendant who, with some companions, was arrested on July 22, 1953 , on a charge of breach of the peace. The charge grew out of an antiwar street meeting which was broken up by the police, and the case against the defendants was eventually dismissed. The account of their detention in the station house suggests how theoretical the accused defendant's protections may be in some cases: ${ }^{89}$

"At the time of booking we asked to make our one legal phone call. The request was repeatedly put off and was never finally granted. Hallman tried again in the morning, no luck."

These defendants were able to obtain counsel only because a friend who had seen the arrest contacted an attorney for them; otherwise they would have had to go on trial in the morning for their summary offense without any chance to contact counsel. Even with an attorney they were unable to effect their release that night:

"Although we had been arrested at 9:30 P. M., no copy of the charge could be secured till 12:55 A. M. By then no magistrate would get out of bed to sign it. So the prisoners had to stay in the lock-up overnight."

After the preliminary hearing defendants who have not posted bail are detained in the untried section of Moyamensing Prison (Philadelphia County Prison). There is no statute applicable to these detainees comparable to the requirement of free communication for those in police custody,,$^{90}$ and conditions of imprisonment are substantially equivalent to those of convicted prisoners. The prison's Board of Inspectors reports: ${ }^{91}$

"Although the [untried prisoners] are segregated and allowed a few special privileges, including additional visitors; the untried prisoner generally must be subjected to the same rules and regulations as the convicted prisoner, as a security measure, due to the limited facilities presently available."

At the time of this study these regulations stipulated that an untried prisoner may write two letters per week, that the prison agent will make calls for the prisoner at the rate of one per week and that members of the immediate family may visit the prisoner for 15 minutes once per

89. See Hallman \& Walker, The Ritrenhouse Square Meeting 3 (mimeo 1953), on file in Biddle Law Library.

90. See note 88 supra.

91. PRISON REP., op. cit. supra note 66 , at 33 . 
week. ${ }^{92}$ The prisoner may write a letter one or two days after his arrival, and thereafter, if he has no money for postage, the county will pay the postage for one letter a month. These "privileges" may be lost if the prisoner is "keyed in," i.e., confined to his cell as a disciplinary measure for disobedience of prison regulations. ${ }^{33}$

Such regulations aggravate the enforced isolation which is the inevitable concomitant of any imprisonment, and are as restrictive as those which exist in many institutions for convicted offenders. The provisions for two letters a week and the opportunity to have someone else make one phone call in his behalf obviously imposed a prohibitive limitation upon a defendant who wished to prepare a defense, and 28 of the 104 prisoners interviewed blamed the communication restrictions for their failure to obtain bail.

If the prisoners' complaints are valid, telephone calls placed through the prison agent sometimes proved to be ineffective as a means of communication. One defendant, trying to contact his mother by phone, was told by the agent that there was no answer, and the agent refused to call again because he thought that the mother certainly knew after four days that the defendant was in prison. Another defendant stated that he had hoped to raise bail either from his brother, who could be reached at his home only in the evening, or from his employer, who was located in the suburbs. The prison agent refused to make either call, the first because he worked only from 9 to 5 , the second because he would not call out of the city. At the time of the interview the defendant had written a letter to his brother and was waiting for an answer. Other defendants complained about the restrictions in the hours during which they could have calls placed. One defendant who came in on Saturday had to wait until the prison agent next came to work on Monday.

The prison agent regarded these complaints as unjustified, stated that rules were relaxed in special cases, and said that he refused to make a phone call only when he felt it would not do any good. ${ }^{94}$ But regardless of the truth of these conflicting allegations, it would seem self-evident that the statutory requirement as to Philadelphia police station confinement, that arrested persons "shall be given the opportunity to promptly communicate with . . . such persons as they desire," 95 should be extended to cover the entire period of pre-trial confinement for all defendants throughout the state. ${ }^{98}$ Provisions for unlimited correspondence and reasonably free access to telephones and visitors would create an administrative burden which seems small when compared with the handicap placed on defendants

92. Letter dated August 26, 1953 from William J. Ruch, Assistant Superintendent, Philadelphia County Prison, on file in Biddle Law Library. There has been an improvement in telephone facilities since this study was made. See text at note 97 infra.

93. Interview, June 1, 1954, with James J. O'Shea, Jr., prison agent.

94. Ibid.

95. See note 88 supra.

96. See suggested remedy at text following note 177 infra. 
who are denied those rights. Such a requirement should provide explicitly that a defendant be permitted to make telephone calls himself, rather than being required to use an intermediary; many defendants complained that the inability to talk directly with persons outside deprived them of the opportunity to make persuasive pleas for help. Since the field study at Moyamensing Prison was made, there has been a small improvement in this direction. At the instigation of the Voluntary Defender, a telephone has been installed from which a defendant personally can make one call immediately upon arrival at the prison; but no subsequent calls can be made and if the number called is answered, that counts as the defendant's one call even if the person he desires to reach is not there. .87

For those defendants who must support families, the problems which are created by pre-trial detention are aggravated. "The situations clamoring most loudly for attention," the Voluntary Defender Association reported in 1953, "involve citizens supporting families from modest earnings who are imprisoned for several weeks to await trial on relatively minor charges. Such imprisonment should be kept at a minimum in view of the disruption to the community occasioned by loss of employment and the necessity for families to subsist on charity and public assistance." 98 Of course, for those who are subsequently convicted and sentenced to imprisonment, this disruption would eventually follow anyway, but in more than half the cases this eventuality does not occur. To a somewhat lesser extent the same consideration applies to defendants without dependents who are employed at the time of their arrest. When defendants are detained, the loss of employment may deprive them of the ability to pay for lawyers; and in the cases in which release follows trial, they may have to resort to public assistance while seeking a new job. For some defendants detention is comparable to imprisonment in lieu of payment of a fine, for a number of those interviewed stated that they could pay for a bail bond if they could only resume their jobs.

Perhaps the most important result of confinement which may influence the less favorable dispositions given to jail defendants is the inability of these defendants when charged with minor crimes to do anything to get their cases dropped. It seems possible that charges initiated by private prosecutors may, when the defendant is out on bail, be settled or dropped informally and that many nolle prosequis may therefore result. However, it is impossible to draw definite conclusions until a careful study is made of the policy underlying the use of nolle prosequi by the District Attorney. This would involve a comparison of its use in cases originated by the police as against those originated by private prosecutors. ${ }^{99}$ A Pennsylvania statute permits private settlements in minor cases and provides that the

97. Interview, note 93 supra.

98. Vol. DeFender ReP., op. cit. supra note 72, at 4.

99. See note 81 supra. 
settlement may be a bar to further prosecution of the charge..$^{100}$ The statute applies to those who, "on complaint of another," are awaiting trial for larceny or fraudulent conversion where the value of the property involved is less than $\$ 200$, or for assault and battery or other misdemeanor "to the injury and damage of the party complaining." If the complainant appears and acknowledges that he has received satisfaction for the damage inflicted upon him, the court may "order a nolle prosequi to be entered on the indictment." In many cases the same result may occur informally by failure of the prosecution witnesses to appear for trial.

If such settlements are widespread the defendant held in jail is being severely prejudiced by his inability to negotiate such settlements and to exert whatever persuasion he can command to this end. Under current regulations he can make one phone call upon admission and none thereafter, and even if the private party is willing to come to the prison the defendant would not be allowed to see him. ${ }^{101}$ When this is considered in conjunction with a jailed defendant's inability to search out evidence and persuade witnesses in his behalf to testify at the trial either to his innocence or in mitigation of penalty, it suggests that the handicap of being in jail may result in a number of convictions which would not occur were the defendant given his liberty during the pre-trial period.

\section{(f) The Conditions of Detention}

The County Prison's Board of Inspectors has noted that "of those detained, the majority must be assumed to be innocent and should be treated accordingly. It is not fair to subject the untried prisoner . . to the same routine as that of the prisoner convicted and serving sentence." 102 It would be possible to lessen the degree of punishment attendant upon pretrial detention by providing relatively pleasant detention facilities in which restrictions upon the inmates were limited to those imperatively demanded by security requirements; one criminologist has suggested "secure individual rooms in buildings equipped much like a clean third-class hotel." 103

The defendants observed in this study, however, were treated almost exactly like convicted prisoners. ${ }^{104}$ The police station detention facilities used prior to preliminary hearing are extremely unpleasant, ${ }^{105}$ and at

100. Pa. Stat. Ann. tit. 19, $\$ 491$ (Purdon Supp. 1953).

101. Visitors are limited to members of the defendant's immediate family. See note 92 supra. For an explanation of why visitors other than members of the immediate family are refused visiting privileges, see the report of the Superintendent of the Philadelphia County Prison, PRISON REP., op. cit. supra note 66, at 15: "(a) Because many inmates are ashamed of the disgrace and don't want it thrown up to them once they get their freedom-'Remember when I saw you behind bars', etc. It is a very practical thought and might save some unpleasant and unhealthy argument. (b) We have not the facilities to permit unlimited visitation."

102. $I d$. at 33 .

103. Taft, Criminology 384 (1942).

104. See text at note 91 supra.

105. The following description was published by defendants who spent the night of July 22-23, 1953, in the 12th and Pine Sts. Police Station: "The cell in which 
Moyamensing Prison the untried prisoner is subjected to an admission routine that the prison's superintendent calls "not much better than stock yard methods," 108 and is then confined in cells built for single occupancy in 1835 which, due to overcrowding, must now often contain two persons. ${ }^{107}$ Despite the "almost insurmountable barriers" due to the age of the buildings and the prison's inadequate facilities and handicaps because of its construction, the institution is reported to be in "clean, well painted, well kept condition." 108

The hardships of such imprisonment are a relatively minor problem compared with the handicaps upon untried defendants which are inevitable with any kind of confinement, but the fact that hundreds of Philadelphia defendants who upon trial are not convicted must serve a pre-trial term of imprisonment under such conditions emphasizes the importance of examining methods for securing attendance at trial without the necessity of detention.

\section{Minimizing the Risk of Non-Appearance}

In addition to its effects upon defendants, securing trial attendance by incarceration is also undesirable because of the cost of such detention. Under present conditions detention facilities in Philadelphia are severely taxed, and the cost in 1952 of maintaining pre-trial detainees a total of 131,683 days was more than $\$ 300,000 .{ }^{109}$ To extend the method of assuring trial attendance by imprisonment to all defendants would require multiplication of present prison facilities and prohibitive expense. 110

Criminal administration assumes that most defendants will be free before trial, and, therefore, it is desirable to examine the problems created by pre-trial freedom and the methods employed to minimize the resulting risk of non-appearance. An evaluation of the efficacy of these methods is important not only to determine how well this policy of freedom

Hallman and Walker were lodged was about $6 \times 8$ feet, with a wooden bench running the length of the cell, and a toilet. After several requests for cleaning equipment, we were given a broom and swept out the cell. During our stay there, 21 bugs of various species were dispatched to their doom, although some escaped to feast upon their sleeping victims later in the night . . Hallman by virtue of winning the toss of a coin slept on the board. The two others in this cell slept on the cement fioor, the soft side of which did not seem to be in evidence. We had to buy our own breakfast in the morning, plus tip extracted for the service." HALLMAN \& WALKER, op. cit. supra note 89 , at $3-4$.

106. ". . . we are milling in and out of prison human beings, daily, in a manner not much better than stock yard methods for cattle . - Our admission of inmates is revolting to the decency of an understanding person." PrIsON REP., op. cit. supra note 66 , at 12 .

11 (1951).

107. Annual Report 1950, Philadelphia County Prison Board of Inspectors

108. Visiting Inspectors' Report in PRISON REP., op. cit. supra note 66, at 93.

109. $I d$. at 31 .

110. Recognition of this fact resuited in 1952 in "a meeting at which the most notorious professional bondsmen voted to go on strike" to protest vigorous enforcement by the District Attorney of laws affecting bail. For an account of this threat and the way in which it was met see DIST. ATT'Y REP., op. cit. supra note 46, at 15. 
works, but also to see what deterrents are available which would make it safe to reduce the proportion of jail cases and thus lessen the substantial sacrifice of defendants' rights which has been found to exist in Philadelphia.

The use of a financial incentive through bail is the product of long tradition, but under modern conditions the extent to which it deters nonappearance will vary greatly depending upon the type of bail which is posted. If the defendant has put up his own property or cash or that of a friend or relative whom he does not wish to harm, the resulting restraint upon the accused may be substantial. The amount of deterrence declines, however, when the defendant purchases a bond from a bondsman or a surety company, ${ }^{111}$ especially if there is no provision for cross-indemnification or if such provision proves to be ineffective. In no case, however, can it be said that the bail jumper "has in reality bought his freedom," 112 for to do so would overlook the deterrent effect of not wanting to be a fugitive. The bail defendant who weighs the advisability of jumping has much more to consider than the often fictitious increased financial loss to which he may be subjected. The likelihood that he will be caught and possibly receive a more severe sentence if convicted may have a much greater impact on a defendant's decision than forfeiture of the bond. Consideration should be given, therefore, both to bail and to non-financial deterrents; for the extent to which the latter can be strengthened presents a method for mitigating the harsh prejudice against the indigent which is an inevitable product of exclusive reliance on financial incentives to induce appearance.

\section{(a) Bail Bonds}

Bonds written in Philadelphia during 1950 were studied to determine the apportionment of bail among private sources, professional bondsmen and surety companies, the forfeiture rates for each of these kinds of bail, and the extent to which forfeited bail is actually collected.113

Of the 10,749 bonds with a total value of $\$ 7,043,700$ written in 1950 , $45 \%$ of the number of bonds or $46 \%$ of the total value came from private sources. Surety companies issued only $16 \%$ by number or $20 \%$ by value, and professional bondsmen issued $39 \%$ by number or $34 \%$ by value. It is believed that this low proportion of surety company business has been due to lax collection on forfeitures, and that the natural effect of the more

111. For the cost of bonds, see text at note 56 supra.

112. Orfield, Criminal Procedure from Arrest to Appeal 127 (1947). Note that for certain minor traffic offenses a defendant may post a sum of money which in the event he does not appear for trial, is forfeited as a fine. This is not really a bail situation, for later appearance is not required if the defendant elects to forfeit his deposit as a fine.

113. Each bond posted before a magistrate during 1950 was listed on dockets in the office of the clerk of Quarter Sessions Court. All bail posted before the bail clerk of Quarter Sessions Court is recorded in that office. The total number of bonds posted was compiled from these records and was broken down as to the source of bail. It was necessary to go back to 1950 because of the time lag of up to a year before trial in bail cases and the further time lapse before it is possible to evaluate collection practices and determine how many fugitives are subsequently apprehended. 
vigorous collection methods inaugurated in the fall of 1952 will tend to alter these ratios radically. In Detroit, where collection of forfeitures is $100 \%$, surety companies write $95 \%$ of the bail, ${ }^{114}$ and a spot check of Philadelphia bail in late 1952 indicated that movement in this direction is already well advanced. ${ }^{115}$

When the accused is scheduled to be tried, notice is issued to the surety ordering him to bring the defendant to court. If the latter fails to appear, the District Attorney sues out the bail and asks for the issuance of a bench warrant; ${ }^{116}$ the surety is then given five days to produce the defendant before judgment will be brought against the surety. If the defendant still does not appear, the surety may obtain a bail piece empowering him to arrest the fugitive on sight.117 Sometime thereafter, when sufficient jumps have accumulated, the District Attorney confesses judgment in court against the respective sureties. ${ }^{118}$

The number of forfeitures, therefore, represents all serious bail jumping, and does not take into account the tactics of non-appearance which are used to cause delay or rescheduling of the case before a different judge. No default will appear on the record if an appearance is made within five days, and no figures were obtained on the extent of such "judge-jumping." These delaying devices serve to complicate court calendars and considerably increase expense to the community, although these problems are minor in comparison to those created by defendants who escape entirely. Remedies for this situation would include the assignment of the same judge to the re-trial, thus removing the incentive for the practice, or, if this is not feasible, suspending the licenses of bondsmen whose clients are persistent offenders.

While tactics like judge-jumping are technically violations of the bond, determination of the effectiveness of the compulsion to appear was measured in terms of breaches which result in forfeiture. Out of the 10,749 bonds written in 1950 there were 264 forfeitures, and of the defendants involved, 162 were still at large in July, $1953 .{ }^{119}$ This forfeiture rate of two and

114. Letter dated May 14, 1953 from E. Burke Montgomery, Clerk of The Recorder's Court, Detroit, Mich., on file in Biddle Law Library.

115. Of a total amount of $\$ 382,450$ bail posted in the office of the bail clerk of Quarter Sessions Court for the months of November and December, 1952, the proportion posted by surety companies had risen to $60 \%$, and that posted by professional bondsmen had declined to $10 \%$ and by private sources to $30 \%$.

116. Information as to practices of the District Attorney's office was received from the Assistant District Attorney in charge of the Bail Division, Stanley Bashman.

117. Pa. Stat. Ann. tit. 19, §53 (Purdon 1930).

118. See Pa. Stat. ANN. tit. 53, $\$ 6995$ (Purdon 1930) for section delegating to the Attorney General of the Commonwealth the duty of issuing process upon forfeitures in Philadelphia County. This power was later delegated by the Attorney General to the District Attorney.

119. This information was obtained from a docket kept by Assistant District Attorney Stanley Bashman, which contained the names of all forfeitures, and the status of the defendants was obtained from trial dockets in the same office. This information was broken down as to the source of bail and the crime of which the defendant was accused. 
one-half percent of all bonds written is comparable to Cleveland's rate ${ }^{120}$ but much higher than that of Detroit, where in a five-year period there were 131 forfeitures on a total of 21,260 bonds, a rate of six-tenths of one percent.121 Pittsburgh officials regard the problem of bail jumping as "negligible" 122 and other cities report that it has occurred "two or three times" in twelve years (Minneapolis) ${ }^{123}$ and once in eleven years (Schenectady, N.Y.). ${ }^{124}$ These estimates suggest a very low forfeiture rate.

Two things should be noted in connection with Philadelphia's forfeiture rate. First, the statistics alone over-emphasize the problem. Forfeitures for serious crimes were rare. There were two bail jumpers among those charged with forgery, five for sodomy, ten for narcotics offenders, and none for burglary, robbery, rape, arson and voluntary manslaughter. ${ }^{125}$ Nearly half (119) of the forfeitures involved gambling, liquor or traffic offenses, and the forfeiture rate drops to $1.35 \%$ when these are subtracted. The other bail jumpers included 34 charged with larceny or other property crimes, 46 charged with assault and battery, and 48 held for miscellaneous offenses, such as prostitution, indecent exhibition, fortunetelling and indecent exposure. Second, the ratio of forfeitures varied sharply according to the type of bail written (see figure 4). Bail supplied from commercial sources had a forfeiture rate more than twice that of privately supplied bail.

One probable explanation for the relatively high Philadelphia forfeiture rate was that only $20 \%$ of the bonds written in 1950 which were later forfeited and never remitted were actually collected. ${ }^{126}$ Although enforcement was strengthened in 1952, collection rates were still less than $50 \% .127$ This is to be contrasted with Detroit, which had one-fourth as many forfeitures under a bail system in which $100 \%$ collection is main-

120. Letter dated July 31, 1953, from Leonard F. Fuerst, Clerk of Courts, Cuyahoga County, Cleveland, Ohio, on file in Biddle Law Library (from 1947 to date of letter an average of 343 bonds posted annually and a total of 51 forfeitures for same period).

121. See note 114 supra.

122. Letter dated June 24, 1953, from James F. Malone, Jr., District Attorney, Allegheny County, Pittsburgh, Pa., on file in Biddle Law Library.

123. Letter dated May 17, 1954, from Michael J. Dillon, County Attorney, Hennepin County, Minneapolis, Minn., on file in Biddle Law Library.

124. Letter dated May 12, 1954, from Emmet J. Lynch, District Attorney, Schenectady County, N.Y., on file in Biddle Law Library.

125. One explanation for this is that far fewer defendants charged with these serious crimes are admitted to bail, but at least some of these defendants are released. See note 68 supra.

126. Out of 215 bonds which were not remitted, only 43 , or $20 \%$ of the total number, were collected. The value of the collected bonds was $\$ 22,200$, or $17 \%$ of the total of $\$ 127,500$ which should have been collected.

127. "In 1952, one hundred ninety-seven judgments having a total value of $\$ 120,000.00$ were entered in cases where defendants had jumped bail. $\$ 20,732.00$ was collected on judgments. Arrangements were made with many bondsmen to pay off in weekly or monthly installments judgments totaling $\$ 35,700.00$. This collection plan is being ever broadened and it is hoped that soon there will be a minimum of old unpaid judgments on the books." DrST. ATT'Y REP., op. cit. supra note 46, at 14-5. 


\section{FORFEITURES BY TYPE OF BAIL}

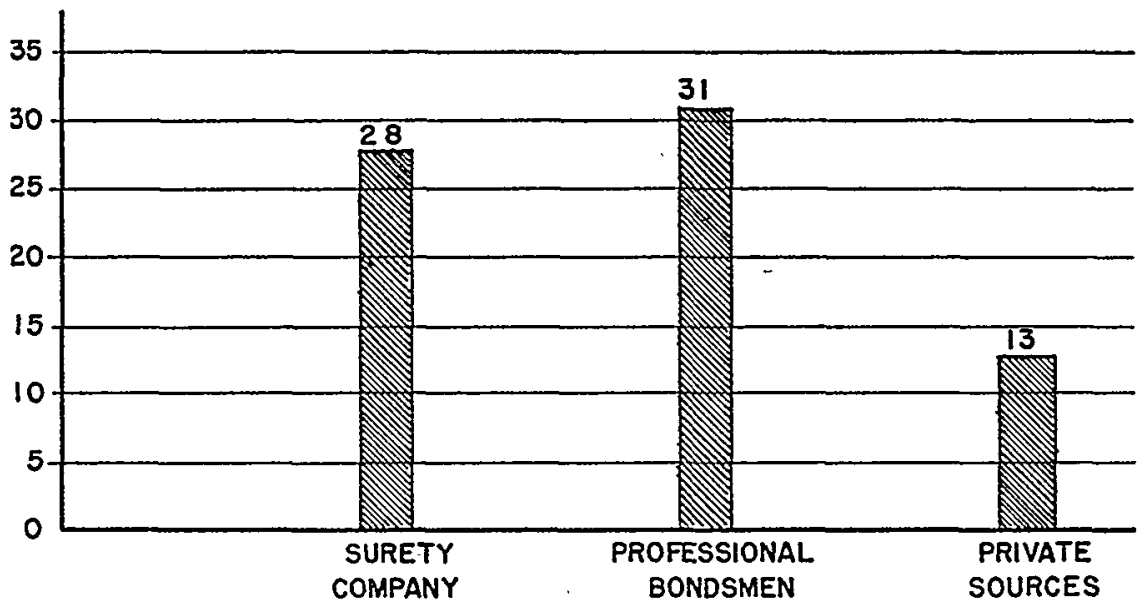

Figure 4. Number of Forfeitures Per 1000 Bonds Written ACCORDING TO SOURCE OF BAIL

tained.128 Methods which could be employed to ensure effective collection need only be mentioned here. ${ }^{129}$ The most important prerequisites are (1) that the system for checking the value of property offered as collateral be sufficient to avert "straw bail" or inadequate collateral; 130 (2) that as soon as bail is posted a lien be imposed upon the property put up as collateral; ${ }^{131}(3)$ that the licensing and regulation of bondsmen require bondsmen to post an initial deposit before being permitted to write any bail; ${ }^{132}$ and (4) that in the event of forfeiture, the bondsman immediately deposit with the court the amount of the forfeited bond. ${ }^{\mathbf{1 3 3}}$.

128. See note 114 supra.

129. See, e.g., ORFIELD, op. cit. supra note 112, at 119-34. See also CourT Rules, THE Recorder's Court For the CITY of DetroIt (Rev. ed. 1951) (hereinaiter cited as DeTroIt RULEs), which offers a "model statute" of proved effectiveness for naximizing collections.

130. See, e.g., Detrort Rules, op. cit. supra note 129, at Rule 9, §4: ". . . before accepting any recognizance" the clerk of court must "verify the following information by means of the telautograph system: a) The Recorded Owner; b) All mortgages, liens, judgments, bonds and recognizances and encumbrances of every kind which appear uncancelled of record; c) Any pending action in which the premises pledged are specifically described; and d) The assessed valuation of the real property as shown by the County Treasurer's Records."

131. For examples see Ill. ANN. Stat. c. 38, §616 (Smith-Hurd 1935) (copy of recognizances in felony cases sent to office of Recorder of Deeds in county where property located, and lien commenced when this is filed); DetroIT RulEs, op. cit. supra note 129 , at Rule $9, \& 10$ (when real estate offered as security, recognizance becomes lien on said real estate).

132. See, e.g., Irt. AnN. Stat. c. 38, §627l. (Smith-Hurd Cum. Supp. 1953). See also, The Municipal Court of Chicago, Rules in Relation to BaIl in Criminal AND Quasi-CrTMINAI Cases, Rules 19, 20 (1952).

133. This is required in Detroit and was described as the court's "great weapon" against bondsmen. See letter dated November 17, 1953, from E. Burke Montgomery, Clerk, the Recorder's Court of the City of Detroit, Mich, on file in Biddle Law Library. 


\section{NUMBER OF FORFEITURES NOT COLLECTED}

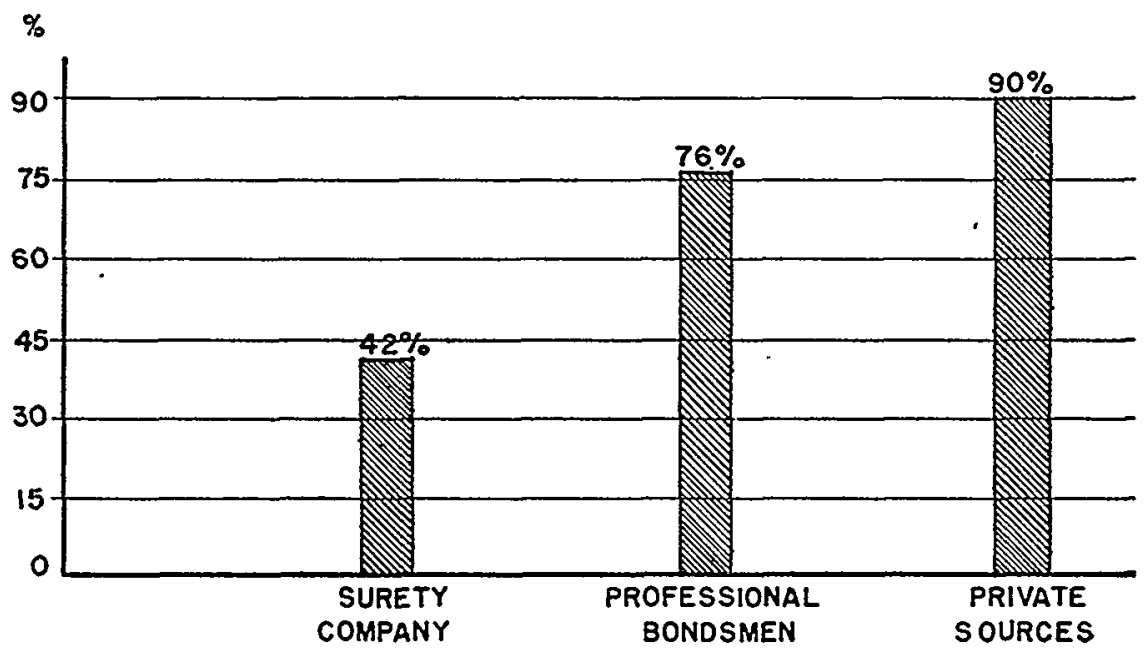

Figure 5. Percentage of Bonds Forfeited, and Not Later Remitted, Which Were Not Collected

The relationship between the rate of collection on forfeitures and the efficacy of bail in compelling appearance which is suggested by the Philadelphia-Detroit comparison is generally assumed to be significant, and, therefore, most bail reform efforts have been directed at improvement of collections. ${ }^{134}$ To the extent that the threat of a financial loss is the incentive which makes the defendant comply, this assumption is logical, for if the threatened loss in fact does not occur the deterrent should lose much of its force. When the Philadelphia figures on collection are broken down by source of bail, however, the results are difficult to reconcile with such a theory. Bail supplied from private sources was the least likely to be collected (see figure 5), yet this was the form of bail which had much the greatest deterrent effectiveness (see figure 4 supra). Furthermore, private bail is apparently unable to exist as a major supply source in the face of strict collection. With stricter collection policies, it declined by one-third in Philadelphia by the end of 1952, and in two other cities with $100 \%$ collection it was doing only $5 \%$ of the business.

These facts suggest the need for careful examination of the ways in which the bail bond system minimizes the risk of non-appearance. If an increased forfeiture collection rate results in a net decrease in the proportion of forfeitures, as it has done in Detroit, the improvement apparently takes place despite the virtual elimination of the only type of bail in which

134. See, e.g., A Study of the Bait Bond System in the District of Columbia 42 (Washington Crim. Justice Assin 1937, mimeo); BeELey, THE BaIL System IN CHICAGo 167-9 (1927); and the reform which led to the present Detroir RuLEs, op. cit. supra note 129. 
the defendant has a strong financial inducement not to become a fugitive. Many factors probably contributed to the comparatively greater efficiency of private bail in producing defendants for trial in Philadelphia. First, the defendant for whom a private bond has been put up knows that if he jumps bail the loss will fall upon the relative or friend who has assumed the risk solely for the purpose of freeing the defendant. The relatively low forfeiture rate for private bail in Philadelphia suggests that, even with low collection, this moral compulsion operates as a powerful deterrent. Second, the private bondsman is probably a friend or relative of the defendant, and thus is in a favorable position to gauge his reliability and to refuse to do business with him if he is a bad risk. Third, the private bondsman can police his risk to some extent because he is likely to see the defendant frequently.

The commercial bondsman, whether operating on his own or as agent for a surety company, is at a comparative disadvantage in all these respects. The defendant is not financially obligated to him because, in the absence of collectible cross-indemnification, the payment of the premium ends the defendant's liability. The moral obligation is also lacking because the professional bondsman does not have the advantageous personal relationship which is the private bondsman's chief weapon. Finally, the commercial bondsman is in an inferior position in selecting and policing his risks. He may know little or nothing about the defendant when he is asked to put up bond, and in addition there are strong pressures upon him to accept even a known poor risk. His business usually comes either from runners, who work on a commission basis and therefore have an incentive to write as many bonds as possible, or from ward politicians, whom the bondsman is unlikely to turn down because they are a frequent source of business. That professional bondsmen do little to eliminate poor risks is indicated by the fact that only one of the 104 jail defendants who were interviewed stated that she had the money for a bail bond but was unable to get anyone to write it. Once he has put up the bond, the professional bondsman has little opportunity to police his risk, for the cost of keeping track of the defendant would be prohibitive and, barring exceptional circumstances, not warranted by the low forfeiture rate. The length of time which elapses before a bail defendant is brought to trial accentuates this problem. One bondsman stated that, upon receiving notice to bring to trial a defendant whom he had not seen since arrest some twelve months previously: "My heart was in my mouth when I knocked on the door of the address listed on the bond. It is impossible to keep track of a defendant for that length of time."

Strict collection increases the bondsman's risk, but there is little flexibility within the system described above by which the surety can protect himself against this increased risk. The private surety is already likely to reject bad risks, while the commercal bondsman is limited in his ability to do much to improve his selection of risks. It may be that, under a bail 
system with strict collection on forfeitures, the proportion of defendants unable to raise bail would rise substantially because of increased discrimination on the part of commercial bondsmen. Since no figures could be obtained elsewhere on the proportion of defendants unable to raise bail, it is impossible to know if one cost of the lower forfeiture rate of a city like Detroit is an increase in the number of jail defendants. However, in view of the pressure upon commercial bondsmen to do as much business as possible and the difficulty of attaining a better selection of risks, it seems unlikely that strict collection would have any marked effect in increasing the number of defendants who can afford bail but who cannot find a bondsman willing to accept them.

There remains only one other way in which strict collection can affect the bondsman's incentive to produce the defendant and this reduce the forfeiture rate, i.e., the increased pressure it places upon him to try to find fugitives. Liberal provisions for remission of forfeitures are designed to make it attractive for bondsmen to recover their losses by finding the defendant who has jumped bail and returning him for trial. ${ }^{135}$ With collection rates as low as they were in Philadelphia for bonds written in 1950, the incentive for bondsmen to spend time and money looking for runaway defendants is not great, and this is doubtless one explanation for the relatively high number of bail jumps for minor crimes in that year. If every forfeiture were reduced to judgment and collection, however, the bondsman would be forced to become a private detective.

This effect of strict collection reveals that the real deterrent force against non-appearance in commercial bail is the threat of apprehension. The private surety is at a great disadvantage compared to the commercial bondsmen in the performance of this function. The friend or relative of an absconded defendant is not able to make an extensive search for the defendant, since it might mean giving up his job and because he normally does not have any contacts which would guide him to the fugitive. It is not surprising, therefore, that as strict collection puts a premium on apprehension, one of its effects is to drive private bail into an insignificant position. It is difficult to determine exactly why the professional bondsman is able to fare better as a detective than the private surety. However, the professional bondsman does have police and underworld contacts which are useful, and in more or less organized areas of crime, such as gambling, it is quite possible that participants will give information to the professional

135. The court may "moderate or remit" forfeitures, PA. STAT. ANN. tit. 17, §502 (Purdon 1930), and even after the judgment has been collected that part of the funds collected which has been allocated to the county may be returned, PA. STAT. ANN. tit. 8, $\$ 177,180,181$ (Purdon 1930). Compare ILL. STAT. ANN., c. 38, §625f (Smith-Hurd 1935) (forfeiture and judgment may be vacated or modified upon showing that within 15 months "the accused person has been apprehended or surrendered, or has died, or has been convicted and imprisoned by some other state or by the United States. . ..."). In Newark, N.J., "the bondsman has four years within which to surrender the absconded defendant. Upon doing so the forfeited money is returned to him $100 \%$, less any expense caused by the county for his apprehension." Letter dated July 3, 1953, from Russell C. Gates, County Clerk, Essex County, Newark, N.J., on file in Biddle Law Library. 
bondsman as to the whereabouts of those who have jumped bail in order to protect their own opportunity to get bail. ${ }^{136}$ Furthermore, giving the bondsman a financial incentive to recapture fugitives would seem to invite a situation in which the police, instead of making an arrest directly, "sell" their knowledge of the defendant's location to the bondsman.

As it seems probable that under a bail bond situation the police do not concentrate on apprehending bail fugitives but leave this task to bondsmen, the result of strict collection will be to lower the forfeiture rate because it induces increased activity by bondsmen directed toward apprehension. In one city where the "very few civil actions pending for the collection of bail" implies a low forfeiture rate, the clerk of the court stated that this was ${ }^{137}$

“. . . due, perhaps, to the fact that personal bondsmen in our county are a very aggresive group and relentlessly pursue the defendant who skips bail on which they are surety and bring them back in very many instances. We have had examples where they have gone out of the country in order to effect the production of a person who has skipped bail. This hard attitude on the part of some of these sureties has put the fear of God into a lot of defendants who know what to expect in the event that they skip bail; so we do not have any particular problem in this regard."

Commercial bail is essentially a transaction in which the bondsmen agree to help the police track down fugitives at the expense of all defendants who pay the premiums for bonds. This may save the state some money, although the cost of administering a bail system probably offsets any economy in police costs. It can also be argued that the threat of having both the bondsman and the police searching for a fugitive would increase a defendant's fear that he will be caught if he jumps bail. It is doubtful, however, if such teamwork is an efficient method of apprehension. It may invite police lethargy and corruption, and it is difficult to believe that the bondsman has sources of information which do not either stem from the police or could be as readily obtained by them. The police alone have the communication facilities, a nation-wide cooperating system and the scientific methods which are keys to successful location of missing defendants. Even if it could be demonstrated that the retention of private law enforcement in this area is efficient, that efficiency must be balanced with the cost of a bail system in terms of pre-trial imprisonment and sacrifice of defendants' rights.

\section{(b) Non-financial Sanctions Against Bail-Jumping}

The effectiveness of ultimate apprehension as a deterrent to bailjumping will partially depend upon the sanction imposed upon the defend-

136. Information that this was done was supplied by a surety company executive who would not permit the use of his name.

137. Letter dated June 24, 1953, from Sidney J. Gottneid, Clerk of the District Court, Douglas County, Omaha, Neb., on file in Biddle Law Library. 
ant for non-appearance. In most jurisdictions the existence of any nonfinancial sanction will depend upon the conviction of the defendant for the offense with which he was originally charged. In such a situation the imposition of a more severe sentence upon a convicted defendant who has jumped bail may often in fact occur, and it is probable that defendants are aware that such increased sentences may be a penalty for bail-jumping. Since there are no other effective non-financial sanctions, however, the threat of an increased sentence may not operate as a deterrent where a defendant, by becoming a fugitive, can materially lessen the chance of conviction because of the resulting delay in his trial.

To remedy this defect, a few jurisdictions punish bail-jumping directly. One federal court has done this by using its contempt power ${ }^{138}$ to punish a defendant's wilful disobedience of an order to appear. ${ }^{139}$ However, the availability of this method is severely limited because it can be applied only if the defendant had actual knowledge of the order to report, and ordinarily the accused would have disappeared before an attempt was made to serve notice upon him.

A more useful sanction was developed in Canada, where the statute penalizing escape from prison or from lawful custody was extended to punish a defendant on bail who, "without lawful excuse," fails to "present himself at the proper time and place." ${ }^{400}$ Thus the bail defendant is treated as if he were in technical custody and bail-jumping is regarded as an unlawful "escape." Statutes patterned on this Canadian model have been adopted in Minnesota ${ }^{141}$ and New York, ${ }^{142}$ and the Department of Justice recently proposed one for the federal system. ${ }^{143}$ The New York Act makes the defendant absolutely liable if he does not appear within 30 days after the forfeiture of his bail; the Canadian Act places the burden of proof upon the defendant to show a "lawful excuse" for his failure; and the Minnesota and proposed federal acts punish "wilful" violations.

The New York and Minnesota statutes have not been widely used. In the latter state, the act was very rarely invoked in two of the most populous counties because "bail jumping is not a serious problem." ${ }^{144}$ A

138. 18 U.S.C. $\$ 401$ (1946).

139. United States v. Hall, 198 F.2d 726 (2d Cir. 1952), cert. denied, 345 U.S. 905 (1953). Compare Collins v. Georgia, 32 Ga. App. 450, 123 S.E. 723 (1924) (held error to declare defendant in contempt for refusing to appear in absence of specific statutory authority).

140. Rev. Stats. of Canada c. $36, \S 189$ (c) (1927), amended by Stats. of CaNada 11 Geo. VI, c. 55, \&2 (1947).

141. Minis. Stats. ANn. $\$ 613.35$ (1947).

142. N.Y. Penal Code $\$ 1694-a$. See People v. Davis, 5 N.Y.S.2d 411, 168 Misc.

511 (1938); People v. Pilkington, 103 N.Y.S.2d 66, 199 Misc. 667 (1951).

143. Dep't of Justice Press Release dated March 25, 1954.

144. "During the past 12 years, I don't believe bail jumping occurred more than two or three times. The Statute has never been invoked in the work of this office. Up to the present time, we have been fortunate enough to convict all bail jumpers and their sentences have been to [state] penal institutions. We have felt that this punishment has been sufficient." Letter dated May 17, 1954, from Michael J. Dillon, County Attorney, Hennepin County, Minneapolis, Minn., on file in Biddle Law Library. See also letter dated May 26, 1954, from Thomas J. Naylor, County Attor- 
similar response was given by some New York prosecutors who were questioned. ${ }^{145}$ In New York County, however, eight or nine cases a month are referred to the Grand Jury, ${ }^{148}$ and in Kings County (Brooklyn), the practice is "to indict in all cases where [the District Attorney] believes the forfeiture is wilful." ${ }^{147}$ Thirteen bail-jumping indictments during the last six years are reported in Brooklyn and the District Attorney believes that the statute is a valuable deterrent because "an experienced bondsman will impress upon his principal the necessity of appearing whenever required to do so and will also make known to his principal the consequences of his failure to do so." 148

Such a statute serves a useful purpose in cases in which there is no other sufficient deterrent against a temptation to flee and avoid or delay trial. It represents a step towards recognition of the fact that the threat of apprehension is the major deterrent against non-appearance, and may foreshadow the day when appearance for trial will be enforced by a criminal sanction instead of by a bail bond system.

\section{Conclusions}

More than twenty years ago the Wickersham Commission pointed to the need for research on bail "in the direction of the individualization of bail determinations based on the history, character, standing, personality and record of the accused." 149 The Supreme Court in Stack v. Boyle ${ }^{150}$ held that such an individual determination was a constitutional requirement, and the concurring opinion of Justices Jackson and Frankfurter stated that fixing "a uniform blanket bail chiefly by consideration of the nature of the accusation [which] did not take into account the differences

ney, St. Louis County, Duluth, Minn., on file in Biddle Law Library (". . . we do not have a serious problem in bail jumping in our county"; statute invoked twice in 25 years).

145. William Kerwick, Assistant District Attorney, Queens County, New York, stated in an interview in June, 1953, that he could recall of its being invoked only once in the past 20 years. See also letter from Emmet J. Lynch, supra note 124 . The statute has been invoked "on occasions" in Buffalo. Letter dated May 13, 1954 from John F. Dwyer, District Attorney, Erie County, Buffalo, N.Y., on file in Biddle Law Library.

146. Letter dated June 4, 1954, from Harold R. Shapiro, Assistant District Attorney, County of New York, New York, N.Y., on file in Biddle Law Library. "Most of the cases of bail-jumping presented to the Grand Juries of this County have resulted in indictments or informations, as the case required, and in most instances these, in turn, have resulted in guilty pleas or have been covered on disposition of the main case." Ibid.

147. Letter dated May 17, 1954, from Edward S. Silver, District Attorney, Kings County, Brooklyn, N.Y., on file in Biddle Law Library. Disposition of these cases included four sentences of imprisonment, two suspended sentences, one sentence to time served while awaiting trial, and three indictments still pending while the defendants are serving their sentences on the principal charges.

148. Ibid. See also letter from Harold R. Shapiro, supra note 146 (the statute "has had a salutary effect in deterring persons from violating the conditions upon which they have been released on bail").

149. Nationat Commission on Law Observance \& Enforcenent, Report on Prosecution 12 (1931).

150. 342 U.S. 1 (1951). 
in circumstances between different defendants" would be "a clear violation of Rule 46(c)." 151

The gulf which separates this goal of individualization from the Philadelphia practices which have been noted in this study is so wide as to suggest that it cannot be bridged. The only kind of "individualization" which was significant was the frequent magisterial practice of assuming that the defendant was guilty and deciding whether or not the circumstances of the offense were such that punishment in the form of high bail was warranted. The nature of the offense was the rule of thumb against which the amount of bail was determined, and factors based on "the history, character, standing, personality and record of the accused" were not developed at all in most hearings. This is not surprising in view of the formidable theoretical and administrative difficulties which stand in the way of individualizing bail according to the risk presented by the particular defendant. The lack of any adequate knowledge upon which to base a determination as to a defendant's reliability appears to present insuperable difficulties in the absence of the kind of research advocated by the Wickersham Commission. ${ }^{152}$

Even the value of attempting such research is questionable, however, because of administrative difficulties which prevent the kind of hearing that would be required for individualization. The relief provided by bail must be speedy if it is to be effective in preventing the punishment of the innocent and the economic dislocation of employed defendants. Release should come as soon after arrest as is practicable, and one of the major defects in Philadelphia practice was that it took an average of five days for defendants charged with serious offenses to obtain bail and be released from jail. Development of the kind of information necessary for genuine individualization would require a practice somewhat comparable to the pre-sentence investigation made by probation departments following conviction. ${ }^{153}$ Yet this takes a week or more of preparation, and the cost of applying such a procedure at the level of the preliminary hearing would be very great. Without such pre-bail investigation, there is no practicable way of obtaining the facts which are required. The preliminary hearing is not adequate to achieve this purpose, for the police information is insufficient and one-sided. A fair hearing for bail purposes would require full participation by an adequately represented defendant. However, in the observed hearings only $15 \%$ of the defendants were represented by counsel and the defendant takes a real risk if he participates at all. The primary purpose of the preliminary hearing is to determine whether or not there is a prima facie

151. Id. at 7,9 .

152. See text at note 26 supra.

153. FED. R. CRIMr. P. 32(c) (2) : "The report of the presentence investigation shall contain any prior criminal record of the defendant and such information about his characteristics, his financial condition and the circumstances affecting his behavior as may be helpful. . . ." 
case; the defendant is warned that anything he says may be used against him, and it is usually to his advantage to say nothing. Yet in the 35\% of the cases in which the question of bail determination was given independent consideration, the discussion was intermeshed with the hearing on the prima facie case, for which purpose the defendant had been cautioned against speaking. Nor are the magistrates who make the decision qualified to exercise the broad discretionary power which individualization must repose in them. The fact that most magistrates in Philadelphia are not lawyers aggravates this problem. While this may not be a major consideration, at least a lawyer-magistrate would be more likely to recognize that the preliminary hearing determines merely whether or not a prima facie case exists, that presentation of the police case does not establish the defendant's guilt, and that the use of bail for punishment is improper.

It seems improbable, therefore, that there can be any substantial improvement in bail determination beyond the kind of practices which were observed in this study. The volume of cases requires the use of a rule of thumb; the fact that hearings are held before the lowest level of the judiciary and that appeals are usually impracticable makes a considerable amount of abuse inevitable; and the employment of a pre-bail investigation to develop information about the defendant would involve prohibitive expense and the denial of bail to all defendants for the time necessary to make the investigation.

In any event, improvement in the method of bail determination would not resolve the central problem of the bail system unless bail for each defendant was to be set for an amount not in excess of what that particular defendant could afford. As long as the yardstick for determining what constitutes excessive bail is the range within which bail is "usually set" for comparable offenses, ${ }^{154}$ there will be defendants who are denied pretrial release. The only resolution of the clash between bail and defendants' rights is to abandon the necessity of bail for defendants who are financially unable to obtain it, and if society can afford to take this risk with indigents, it can take it with all defendants.

The feasibility of such a step depends upon the extent to which it might increase the number of fugitives. Since most bail is commercially provided, the financial deterrent against bail jumping is usually fictitious. If there were an appropriate criminal sanction against non-appearance which was directly enforced by the police, it is extremely improbable that there would be any increase in the number of fugitives from among those who now post bail.

The unknown risk which the abandonment of bail would require society to assume is the possibility that the type of defendants who are now jailed are so much more unreliable as a group that their pre-trial freedom would substantially increase the incidence of non-appearance. It is impossible

154. See note 16 supra. 
to determine how much weight should be given to this possibility; ${ }^{155}$ the untested assumption that there is a high correlation between financial inability and the likelihood of non-appearance is the strongest argument for the retention of bail.

This risk can be minimized in several ways. First, the enactment of a law which penalizes failure to appear in court when ordered would invoke a direct deterrent against trying to flee. Second, speeding up the trial of bail cases would decrease both the opportunity for a defendant to commit new crimes while awaiting trial and would operate as an indirect preventive to reduce non-appearance. Defendants who have little tie to the city are much more likely to wander off if their case will not be reached for nine months than would be the case if trial followed preliminary hearing by not more than a few weeks.

With such correctives the degree of risk created by releasing the jailed defendants does not appear to be large. When this risk is weighed against the substantial impairment of defendants' rights which is the concomitant of the present system, an unwillingness to experiment in the direction of the abolition of bail perpetuates the overemphasis on security at the expense of individual rights which is an anomaly in our system of criminal justice.

\section{RECOMMENDATIONS}

The recommendations which follow fall into four categories: (1) a statute which makes non-appearance a criminal offense and thus establishes a deterrent against non-appearance as an alternative to or substitute for bail; (2) recommendations designed to increase the number of defendants released without security on their own promise to appear, and to improve the procedure for obtaining pre-trial release; (3) lowering of the standard amount of bail which is now set for many offenses; and (4) methods by which defendants who are detained pending trial can be assured of the right

155. In this study, social histories were obtained from 104 prisoners who were interviewed, but it was not feasible to verify the information from other sources. In any event such information would have limited value unless it was compared with an analysis of the social histories of bail defendants, whom it was not feasible to interview.

The unverified social histories which were obtained in general agreed with those of BEELEY, op. cit. supra note 26 , at 157-9, that: (1) "contrary to expectations, the unsentenced Jail prisoners are not transients, taken as a whole"; (2) they are usually single or separated; (3) they are "for the most part rocationally unskilled"; and (4) they are usually young, which in part accounts for their economic incapacity and single status.

Compare Beeley's attempt to classify 170 pre-trial detainees, as a result of which he decided that "at least 65" were "dependable" and could safely have been allowed their freedom. Id. at 159. This classification was made by two field workers and one psychiatrist on the basis of information obtained from interviews with the prisoners and a study of their social case histories. No comparative study was made to measure bail defendants by the same standards to see if there were significant differences between the two groups. An added difficulty with according much weight to Beeley's classification is that his conclusions are unverified because the central problem of bail determination, i.e., how to determine reliability, was assumed. Beeley decided what factors indicate dependability and then measured the defendants against this untested assumption. 
to communicate freely with persons outside the jail, thus reducing the handicap which is caused by pre-trial confinement. No separate recommendations are made here for improving the efficacy of collection of forfeited bail, suggested remedies having been previously discussed. ${ }^{156}$

\section{(1) Making Non-appearance a Criminal Offense}

The ultimate abolition of the bail system is the only solution for the prejudice to jail defendants which results from their low economic status. A prerequisite for this development is a statute which sets up a direct sanction against non-appearance. The statute proposed in the margin ${ }^{157}$

156. See text at notes 129-33 sipra.

157. While this study was limited to an examination of problems concerning defendants held pending trial, see note 1 supra, the following proposed statute is drafted to include persons bailed or otherwise released after conviction, pending an appeal or pending appearance as a witness.

The purview of the proposed statute follows:

Section 1. Whoever, having been charged with a criminal offense, or having been held for appearance as a witness, and having been admitted to bail, or served with a summons to appear for a preliminary hearing, or otherwise released pending appearance as a witness or for a preliminary hearing or for trial or pending the outcome of an appeal, does not, without lawful excuse, present himself at the proper time and place, is guilty of an offense, and, upon conviction in a summary proceeding, shall be sentenced to a fine not exceeding one hundred dollars $(\$ 100)$, or to imprisonment not exceeding thirty (30) days, or both.

Section 2. Whoever violates Section 1 of this Act and, in addition, does not surrender himself within thirty (30) days following the date of his failure to appear, if bail was given or release obtained in connection with a charge of felony or pending appeal or certiorari after conviction of any offense, is guilty of a felony, and, upon conviction, shall be sentenced to pay a fine not exceeding five thousand dollars $(\$ 5,000)$, or to imprisonment not exceeding five (5) years, or both.

Section 3. Whoever violates Section 1 of this Act and, in addition, does not surrender himself within thirty (30) days following the date of his failure to appear, if bail was given or release obtained in connection with a charge of committing a misdemeanor, or for appearance as a witness, is guilty of a misdemeanor, and, upon conviction, shall be sentenced to pay a fine not exceeding one thousand dollars $(\$ 1,000)$, or to imprisonment not exceeding one (1) year, or both.

Section 4. In all proceedings under this Act, proof that the defendant did not present himself at the proper time and place is prima facie evidence of a violation of this Act.

Section 5. A person admitted to bail or otherwise released pending appearance before any court shall furnish his address and shall give written notice of any change of address to the District Attorney and the clerk of the court before which he is to appear. Whoever furnishes a false address, or fails to give written notice of any change of address to the District Attorney and the clerk of the court before which he is to appear within 48 hours after he has changed his address, is guilty of an offense, and, upon conviction in a summary proceeding, shall be sentenced to a fine not exceeding one hundred dollars $(\$ 100)$, or to imprisonment not exceeding thirty (30) days, or both.

Section 6. Before a person is admitted to bail or otherwise released pending appearance as a witness or for preliminary hearing or for trial, he shall be photographed and fingerprinted, and shall be given a written notice clearly explaining the requirements and penalties provided for by this Act. If such person is released pending a preliminary hearing, he shall be served with a summons which shall state clearly the time and place at which he is to appear. If such person is released pending appearance as a witness or defendant before any court, he shall be given at least five (5) days notice by registered mail of the time and place at which he is required to appear. 
provides a severe penalty for fugitives who do not appear within 30 days of the time required; proscribes "judge-jumping" by providing a lesser penalty for those who do not appear on the day required but do appear within 30 days; protects the defendant when he has a lawful excuse for nonappearance, but makes proof of non-appearance constitute prima facie evidence of a violation; and protects both the state and the defendant by requiring fingerprinting before release and by appropriate notice provisions.

\section{(2) Reduction in the Use of Bail}

A marked reduction in the incidence of pre-trial detention could be achieved by legislation which would utilize a summons instead of arrest in proper cases ${ }^{158}$ and which would require that a defendant charged with a minor offense be released without bail on his own promise to appear unless it was shown that the individual circumstances of the case give rise to a reasonable belief that the defendant will probably flee the jurisdiction.

A statute authorizing the use of the summons should (1) require its use for defendants charged with minor offenses and (2) permit it to be employed in any case in which the defendant is bailable as of right. ${ }^{159}$ The proposed statute penalizing non-appearance ${ }^{160}$ includes those who fail to appear after being served with a summons and would obviate the necessity for police station confinement pending a preliminary hearing in many cases. ${ }^{101}$

Even if the power to release a defendant on his own recognizance without bail is recognized, as in Pennsylvania, ${ }^{162}$ there should be specific legislation to govern and encourage its use. Bail was required in almost every state case studied and the Pennsylvania case authorizing release

158. E.g., Mass. ANv. LAws c. 276, $\S 24-5$ (1933) : "Upon a complaint for a crime punishable by fine only, or by imprisonment for not more than one year, with or without a fine, a summons may be issued instead of a warrant for arrest, if, in the judgment of the court or justice receiving the complaint, there is a reason to believe that the defendant will appear upon a summons." Provision is made for service "not less than twenty-four hours before the return hour."

159. The following form is recommended:

In all cases in which the offense which the defendant is alleged to have committed is an offense which can be tried summarily, or a misdemeanor, or larceny or fraudulent conversion where the value of the property involved is less than $\$ 200$, prosecution shall be begun by summons instead of by warrant of arrest. In no such case shall any warrant of arrest be issued except upon affidavit showing reasonable cause to believe that the defendant will probably flee the jurisdiction. In any other case which is bailable as of right, prosecution may be initiated by summons instead of warrant of arrest, whenever there is no reasonable cause to believe that the defendant will probably flee the jurisdiction.

Compare the similar but less extensive provisions of Senate Bill No. 459, Session of 1953, Pennsylvania Legislature.

160. See note 157 supra.

161. If it was necessary to photograph or fingerprint the defendant, he could be taken into custody for this purpose and then served with a summons and released. The same procedure could be followed in the case of a defendant arrested on sight.

162. McNair's Petition, 324 Pa. 48, 187 At1. 498 (1936). 
without bail added that this "is a practice not to be recommended or encouraged." 163 Specific legislative direction will be required to reverse this trend. It is particularly important to require pre-trial release in cases in which Pennsylvania authorizes private settlement in lieu of prosecution, ${ }^{164}$ unless there are circumstances creating an exceptional risk of nonappearance. Pre-trial detention deprives defendants of this remedy, and existence of the provision for private settlement indicates a judgment ${ }^{\circ}$ about the minor nature of the offenses which makes pre-trial imprisonment particularly unjustifiable. The statute proposed in the margin ${ }^{105}$ encourages the use of release without bail in all cases in which there is no unusual risk of non-appearance, and enables greater utilization of the provision for private settlement.

Another recommendation which will reduce the incidence of pre-trial detention is a requirement that a defendant who is in custody be given a prompt preliminary hearing at which bail will be set in all cases. The division of responsibility in Pennsylvania, under which magistrates cannot set bail for serious offenses, resulted in Philadelphia in a substantial infringement of the constitutional right to bail. ${ }^{186}$ Under this procedure, some defendants were unaware of their right to bail, bail was never set for many defendants, and those who did obtain release were detained five days or longer after their preliminary hearing before release was effected. The recommended statute ${ }^{\mathbf{1 6 7}}$ abolishes this division and requires that bail shall be set in all cases when the defendant is first brought up for preliminary hearing, preventing prolongation of the period of police detention by a continuance of a preliminary hearing in a case for which the magistrate cannot now set bail.

163. Id. at 55, 187 Atl. at 501.

164. See note 100 supra.

165. The proposed statutory provision follows:

A person charged with a misdemeanor, or with larceny or fraudulent conversion where the value of the property involved is less than $\$ 200$, and who at his preliminary hearing is held for court, shall be released without bail on his own promise to appear unless it is shown that there is reasonable cause to believe that the defendant will probably flee the jurisdiction. A person charged with any other offense which is bailable as of right may be released without bail on his own promise to appear whenever there is no reasonable cause to believe that the defendant will probably flee the jurisdiction. As used in this Act, "reasonable cause to believe that the defendant will probably flee the jurisdiction" shall be construed to effectuate the purpose of this Act to facilitate the release of defendants pending trial.

166. See text at note 49 et seq. supra. hearing:

167. Proposed statute to enable bail to be set in all cases at the preliminary

Whenever a person is in custody pending his preliminary hearing, the preliminary hearing shall be held not later than noon on the day following the person's arrest. If the preliminary hearing has not been held by that time, the defendant shall be released without bail and served. with a summons. In all cases where the defendant is bailable as of right, bail shall be set or the defendant released without bail on his promise to appear when the defendant is first brought up for preliminary hearing. 


\section{(3) Limitation on the Amount of Bail}

One of the most important problems examined by this study is the restriction on pre-trial release due to the high level of the standard amount of bail which is customary for many offenses. The objective of bail is to secure the release of as many defendants as possible, and this is sought to be achieved by the constitutional outlawry of excessive bail. We have seen, however, that the standard which is applied to determine the excessiveness of bail is whether or not the amount is within the range customarily set for like offenses, ${ }^{168}$ and that this range is an irrational product of custom. ${ }^{169}$

This study suggests the feasibility and desirability of a much more specific yardstick against which to measure whether bail is excessive, i.e., that absent special circumstances showing a high risk, bail is excessive if it is set in an amount higher than that which in practice most defendants can raise. In this study it was found that in magistrates' court, if bail was set at a figure below $\$ 500,85 \%$ of defendants obtained release; if bail was set at a higher figure, the number of defendants obtaining release decreased until, for bail of over $\$ 1000$, only $32 \%$ obtained release. ${ }^{170}$ For the offenses for which bail was set by Quarter Sessions Court, in an amount averaging over $\$ 1000$, only $25 \%$ of the defendants obtained pre-trial release. A bail of not over $\$ 1500$ is within the standard range customarily set for many offenses, yet such a bail is high enough to imprison most defendants. The customary range itself is therefore excessive for the purposes of securing the release of most defendants.

The fact that makes it extremely difficult to achieve a rational method of controlling the amount of bail within the bail system is that variations in amount have almost no relationship to the weight of the deterrent force against bail jumping. As most bail is provided by unsecured commercial bonds, "an excessive bail merely means the enrichment of the bonding company," ${ }^{171}$ with the higher amount resulting in no added deterrent against non-appearance. The only instance in which high bail would be justified is in the case of a defendant who had financial resources which he would risk losing were the bail to be forfeited. This would be true only if the defendant put up his own property as bail or as security for a commercial bond, which is a rare situation confined to defendants who are comparatively responsible financially. The conclusion is inescapable, therefore, that the real purpose of high bail is to incarcerate defendants, a result which the constitutional limitation against excessive bail is designed to prevent but for which purpose it is presently ineffective.

The recommended provision reflects a functional definition of excessive bail by providing that no bail shall be set in an amount higher than

168. See text at note 16 supra.

169. See text preceding note 26 supra.

170. See figure 1 in text preceding note 4 supra and figure 2 in text preceding note 6 supra.

171. Yankwich, Release on Bond by Trial and Appellate Courts, 7 F.R.D. 271, 275 (1947). 
$\$ 500$ except under special circumstances where the higher amount would not prevent the release of the defendant and would result in an added deterrent against bail jumping. ${ }^{172}$ The figure of $\$ 500$ is chosen because of the sharp rise in the number of defendants who cannot raise bail in an amount above that figure. Such a provision is no help for the impecunious defendant who cannot post even this much bail and to that extent discriminates arbitrarily against the indigent. As has been indicated, there is no solution for that problem short of the abolition of bail, and this recommendation is at best a compromise with that goal.

Because this limitation will severely restrict the use of high bail for the deliberate purpose of incarcerating defendants pending trial, mention will be made of two ways in which objectives which typically prompt the use of excessive bail can be remedied.

If it is feared that the defendants will commit further crimes if released on bail, the remedy is not preventive detention but a prompt trial.173 Administrative procedures could be evolved to achieve this end, and in Philadelphia some progress has been made in this direction with narcotics and numbers offenders. ${ }^{174}$ One problem connected with speeding up trials in cases in which there is an apparently high risk of further criminality is the Pennsylvania requirement that all defendants be indicted by the grand jury. The Philadelphia District Attorney has recommended a constitutional amendment to eliminate the grand jury entirely, ${ }^{175}$ but even without this change it is possible to speed up the indictment process and bring the defendant to trial in a very short time. A speedy trial is a much more

172. The recommended statute provides:

Whenever bail is required, the amount set shall not exceed $\$ 500$ unless it is shown, in addition to the fact that the circumstances of the case are such as to create a high risk that the defendant will not appear, that

(a) there is reason to believe that the defendant is able to afford the higher amount of bail; and

(b) there is reason to believe that the result of imposing higher bail will be to make it more probable that the defendant will appear for his trial than would be the case if the amount of bail was not in excess of $\$ 500$.

In any case in which bail is set in excess of $\$ 500$ in accordance with this section, the record shall state with particularity the findings of fact upon which the court or magistrate relied.

173. "From time to time, armed robbers or narcotics peddiers who have exercised this Constitutional right [to bail], commit a second crime while awaiting trial for the first crime. Great excitement then enstues and some people argue that the defendants should never have been at liberty on bail. This in turn leads to criticism of the Courts, which is unjust since they are sworn to uphold the Constitution and, therefore, they must fix bail and may not fix unreasonable bail. The best way to eliminate a bad bail situation is the prompt trial of bail cases. That can be accomplished in Philadelphia if there is a further increase in the number of court rooms devoted to criminal trials. Such an increase would raise numierous questions of man power but, by proper planning, all such problems can be solved." DIST. AIT'y REP., op. cit. supra note 46 , at 14 .

174. "Numbers cases are down to a four month wait and narcotics to two. We try to speed up the numbers cases because they involve men and women who have set out deliberately to break the law. The narcotics cases need quick handling because of the danger of having such people at large." First Assistant District Attorney Michael von Moschzisker, quoted in The Philadelphia Inquirer, Feb. 15, 1954, p. 1, col. 1 .

175. Dist. ATr'y ReP., op. cit. supra note 46 , at 40. 
satisfactory solution than the use of imprisonment to prevent crimes which have not yet been committed. Such imprisonment is repugnant to our theory of criminal justice and is particularly objectionable when, as was often the case in Philadelphia, high bail was the method used to obtain preventive detention. In such situations, the decision that the defendant is a potential offender is merely a guess by the magistrate, court or District Attorney, without any hearing on the factors relevant to such a risk.

If the basis for fearing that a defendant will harm other people if released pending trial is a belief that the defendant is mentally ill, or a mental defective, drug addict, inebriate or epileptic, the proper remedy is to obtain commitment under the provisions of statutes governing the mentally ill. ${ }^{176}$

\section{(4) Rights of Defendants Detained Pending Trial}

As long as defendants are to be imprisoned pending trial, there should be a statutory declaration of the rights to which they are entitled while so confined. As such detention is solely for the purpose of assuring the defendant's appearance at his trial and not for punishment, the element of punishment which inevitably accompanies any deprivation of liberty should be minimized so far as is possible. Ideally this would involve separate detention facilities where the only restrictions would be those imperatively required by considerations of custody. ${ }^{177}$ However, such a remedy would involve so great an expense that it is impracticable, and even ideal detention facilities would still punish the untried defendant and severely prejudice him in his efforts to prepare a defense. The recommendation which is made is therefore limited to guarantees of free communication between the untried defendant and the outside world. These provisions would involve relatively minor expense to the state and are so obviously required to prevent unnecessary aggravation of the prejudicial effects of pre-trial detention that this added expense is fully justified.

Legislation to this end should include the following guarantees:

(a) Any defendant who is detained pending preliminary hearing or after being committed for trial shall be permitted to use the telephone with reasonable frequency, to see any visitor or visitors who come to see him, and to write and receive an unlimited number of letters.

(b) The statute should provide specifically that the defendant shall be permitted to use the telephone a reasonable number of times immediately upon being booked at a police station or upon being admitted to a jail or prison; that he should be supplied with stationery and postage and permitted to write at least three letters immediately upon admission; and that, if he is without funds, he shall thereafter be provided with a reasonable number of free telephone calls and postage for a reasonable number of letters per week.

176. Pa. Stat. Ans. tit. 50, $\$ 1072,1201,2053$ (3) (Purdon 1954).

177. See note 103 supra. 
(c) Specific provision should be made so that a defendant can contact a professional bondsman if he so desires. For this purpose, each police station, jail or county prison should be required to keep and show to each defendant an alphabetical list of the names, addresses and telephone numbers of all licensed bondsmen in the county. ${ }^{178}$

Employment of an effective sanction to force compliance with such a statute raises a very difficult problem. Criminal and civil sanctions against anyone who wilfully deprives a defendant of his rights under the statute probably should be provided, although such remedies are notoriously ineffective when, as in this situation, they must be applied against law enforcement officers. ${ }^{179}$ The civil cause of action would be more effective if it provided for a waiver of sovereign immunity so that the city or county involved would be jointly liable with the offending officer, and if the statute provided for the recovery of damages of not less than $\$ 500$. Probably such a statute cannot be effectively enforced unless vigilant supervision is maintained by voluntary defender associations, bar associations and other groups concerned with individual rights. It is nonetheless important, however, as a standard in seeking improvement of the conditions under which untried defendants are confined.

\section{SuMMary}

Some of the foregoing recommendations represent basic reforms. The use of the summons would eliminate many police detentions, while the requirement of release without bail in most cases in which the defendant is charged with a minor offense would materially reduce the pre-trial jail population. Greater limitation on the maximum amount of bail which can be set and improved procedures to speed up setting bail would make pretrial release more feasible for defendants charged with more serious offenses, most of whom are now detained pending trial.

Such proposals, however, minimize rather than solves the problem of pre-trial detention. Permitting a magistrate to require bail even for defendants charged with minor offenses, where he finds a probability that the defendant will flee, opens the door to probable abuse, while the use of bail even in small amounts will force pre-trial imprisonment of those with very limited financial ability. The premise upon which the bail system was founded, that we should not imprison a person who was merely an accused, can be realized only if a direct penal sanction is substituted for the bail system as the deterrent relied upon to compel appearance in court. Reforms within the bail system are at best temporary expedients pending a time when abolition of the wrongs inherent in pre-trial imprisonment is more highly valued than the usually fictitious deterrent force provided by modern commercial bail.

178. This practice is reported in A Study of THE BAII Bond System IN THE District of Columbia 14 (Washington Crim. Justice Ass'n 1937 mimeo).

179. See, e.g., the dissenting opinion of Mr. Justice Murphy in Wolf v. Colorado, 338 U.S. 25, 41 (1949), discussing the limitations of criminal and civil sanctions against unlawful search and seizure. 